\title{
Environmental Security and Freshwater Resources: Ecosystem Regime Building
}

\author{
Jutta Brunnée and Stephen J. Toope \\ Version Publisher's Version \\ Citation Jutta Brunnée, "Environmental Security and Freshwater Resources: \\ (published version) Ecosystem Regime Building" (1997) 91 American Journal of \\ International Law 26-59. \\ Copyright / License Reproduced from JSTOR. "Environmental Security and Freshwater \\ Resources: Ecosystem Regime Building” (1997) [91] American Journal \\ of International Law [26-59], by permission of Cambridge University \\ Press. Stable URL: http://www.jstor.org/stable/2954139
}

How to cite TSpace items

Always cite the published version, so the author(s) will receive recognition through services that track citation counts, e.g. Scopus. If you need to cite the page number of the author manuscript from TSpace because you cannot access the published version, then cite the TSpace version in addition to the published version using the permanent URI (handle) found on the record page.

This article was made openly accessible by $U$ of $T$ Faculty. Please tell us how this access benefits you. Your story matters. 


\title{
ENVIRONMENTAL SECURITY AND FRESHWATER RESOURCES: ECOSYSTEM REGIME BUILDING
}

\author{
By Jutta Brunnée and Stephen J. Toope*
}

\section{INTRODUCTION}

We have previously argued that international environmental law does not adequately promote environmental security because it has failed to adopt an ecosystem orientation. In this paper we suggest that environmental security in the context of freshwater resources can only be achieved through a sophisticated understanding of regime formation and elaboration, linked with a determined pursuit of ecosystem orientation. Our underlying assumptions are twofold. First, the protection of shared water supplies is a "good" worth promoting, whether for intrinsic or instrumental reasons. ${ }^{1}$ Second, whenever a resource is shared, ${ }^{2}$ particularly a resource that can easily be exhausted or degraded, disputes between the states involved are inevitable. Perhaps surprisingly, we have suggested that the security dimension of the problem relates not only to the potential for disputes, but also-even primarily - to the first of our underlying assumptions. Thus, scarcities of resources should also cause concern when they threaten to undermine either the way of life of a given human population or internal structures of governance and activity through the fostering of subnational conflict and the significant reduction of options for action. In this sense we agree with Richard Ullman's now-famous attempt to redefine the very concept of security. In his view, and ours, a threat to security includes

[any] action or sequence of events that (1) threatens drastically and over a relatively brief span of time to degrade the quality of life for the inhabitants of a state, or (2) threatens significantly to narrow the policy choices available to the government of a state or to private, nongovernmental entities (persons, groups, corporations) within the state. ${ }^{3}$

This approach clearly moves away from the narrow, military focus of much national security analysis. Indeed, it questions whether security should be conceived of merely in terms of the state. Threats to environmental security will often transcend borders, and will not always pit state against state in predictable ways.

We do not believe that the adoption of a wider notion of security need imply that all issues of environmental degradation must fit within the framework of interstate conflict. ${ }^{4}$ Indeed, the key point, as neatly phrased by Geoffrey and David Dabelko, is that " $t \mathrm{t}] \mathrm{he}$ conception of security must instead be changed to reflect the threats of environmental

* Assistant Professor, Faculty of Law, University of British Columbia; and Associate Professor, Faculty of Law, McGill University, respectively. This article was prepared with the financial assistance of the Cooperative Security Programme of the Department of Foreign Affairs and International Trade of the Government of Canada. In our work we were ably assisted by Janice Miller, Sean Muggah, Charlotte Ong, Hiroko Sawai, David Short, Jay Sinha and José Vicente Zapata Lugo.

' See Jutta Brunnée \& Stephen J. Toope, Environmental Security and Freshwater Resources: A Case for International Ecosystem Law, 5 Y.B. INT'L ENVTL. L. 41 (1994). We therefore leave aside, for the time being, whether a shared freshwater regime must be rooted in identified common interests of states or in a more generalized appreciation of good that might transcend state interests. This issue will be addressed in the text at and notes 91-96 infra.

"We use the term "shared" here simply to refer to the physical sharing of freshwater supplies, and not in the technical sense the term "shared natural resource" has acquired in the legal debate. On the concept as a technical term, see Brunnée \& Toope, supra note 1, at 58-59.

${ }^{3}$ Richard Ullman, Redefining Security, 8 INT'L SECURITY 129, 133 (1983).

${ }^{4}$ David Deudney, The Case Against Linking Environmental Degradation and National Security, 19 MILlENNIUM 461, 461 (1990). 
degradation." ${ }^{5}$ We have previously traced the outlines of such a conceptual change in relation to environmental security:

[T] he term environmental security should be understood as two-dimensional. The expansive sense of the concept calls on us to consider the environment per se, even if from a homocentric and instrumentalist position, in assessing the consequences of policy decisions. The security referred to is the maintenance or re-establishment of ecological balance. On the other hand, in emphasizing the dimension of security in the traditional sense of state integrity, the term refers to the prevention or management of conflict over scarce or degraded resources. ${ }^{6}$

Although both senses of the term retain currency and relevance, we argue that the expansive understanding of environmental security is more likely to aid us in effective regime building, and in appropriate normative evolution within regimes. Emphasizing, even if as a matter of human concern, the security of the environment per se is important for at least two reasons. First, only such an emphasis will permit regimes to effectively address the root causes of conflict. A focus on the prevention of conflict alone cannot ensure security in the longer term. In fact, conceptualizing "environmental security" as primarily concerned with potential conflict over scarce or degraded resources may detract from the goal of security by reinforcing the already-prevalent perception of environmental degradation and scarcity as matters of purely national concern. Thus, a second reason for adopting an expansive understanding of environmental security with particular emphasis on protection of the environment itself is the need to highlight common concerns that can help to counterbalance the preoccupation with competing state interests.

Our argument that environmental security can only be achieved through an ecosystem orientation of international norms and regimes flows from the above understanding of the concept. We assume that, at least in the longer term, only freshwater regimes built upon ecological criteria can ensure the security of the environment itself. ${ }^{7}$ We further suggest that this approach will help to focus attention on the ultimate beneficiaries of security, which are not states, but individuals and communities. ${ }^{8}$ With an ecosystem orientation, negotiations will not so easily resolve into debates over competing national uses or equitable shares. Protection of the freshwater resource for humanity today and in the future will take on an independent value. We believe that this holds true both for regimes designed to involve industrialized countries and for regimes addressed to developing countries, which may be understandably inclined to accord priority to economic development. ${ }^{9}$

A broader understanding of environmental security and an ecosystem orientation in norms and procedures do not demand a naive commitment to cooperation as an exclusive model for state behavior. Our proposed reconceptualization of environmental security acknowledges the continuing interplay between competitive statist behavior and an admission that concern for the environment per se and the interests of people might push states toward more cooperative strategies. Through the promotion of various environmental regimes, the goal is to move the normative evolution along a path from preoccupation with the allocation of resources toward ecosystem integrity, without ignoring the continu-

\footnotetext{
${ }^{5}$ Geoffrey Dabelko \& David Dabelko, Environmental Security: Issues of Conflict and Redefinition, in WoodROW Wilson Center, Environmental Change and Security Project Report 3, 8 (1995).

${ }^{6}$ Brunnée \& Toope, supra note 1 , at 46.

${ }^{7}$ In light of its greater currency, we retain the term "environmental security" rather than adopt alternative terms such as "ecological security." On the latter concept, see, e.g., Alexandre Timoshenko, Ecological Security: Global Change Paradigm, 1 Colo. J. INT'L ENVTL. L. \& POL'Y 127 (1990).

${ }^{8}$ See Simon Dalby, Security, Modernity, Ecology: The Dilemmas of Post-Cold War Security Discourse, ALternativeS, Winter 1992, at 95; see also Norman Myers, Ultimate Security: The Environmental Basis of Political STABILITY 31 (1993).

${ }^{9}$ See infra note 14 .
} 
ing power of states to shape the ultimate elaboration of international legal regimes. Therefore, in speaking of ecosystem orientation, we wish to highlight the need to reorient international law. It must move from a perception that environmental degradation is legally relevant only where sovereign interests of states are affected, toward a framework that also evaluates state conduct according to ecological criteria. It is in this sense, then, that we have called for the development of an "international ecosystem law." 10

The principal goal of this paper is to draw together the literature of international regime theory and of international law, particularly what we have called international ecosystem law, with a view to promoting the elaboration of effective regimes to order the relations of states sharing freshwater resources. Our hypothesis is that the insights of regime theory help to explain how binding legal norms may emerge from patterns of expectation developed through coordinated discussions and actions of states in given issue-areas. We will argue that regimes are not static structures. Nor is there a single, all-encompassing definition of a regime. Rather, we postulate that regimes evolve along a continuum from dialogue and sharing of information, to more defined frameworks for cooperation, to binding norms in a more precisely legal sense. All points on the continuum are significant and independently valuable. Although the professional instinct of the international lawyer is to seek to negotiate "binding" agreements, the prelegal or what we will call the "contextual regime" may actually be more effective in guiding the relations of states. In any event, as we shall explain later, the contextual stage of regime formation is typically a precursor to the elaboration of binding norms. As such, it should be valued by the international lawyer.

We wish to emphasize that this continuum of regime formation is not strictly linear. As complex institutions, ${ }^{11}$ regimes help to shape attitudes and actions concerning a range of questions within a given issue-area, and they allow for overlapping cycles of cooperation and competition. This allowance for the continuing interplay between cooperative and competitive behavior is one of the most useful explanatory elements of regime theory, and helps to reorient the analysis of "security" along the lines suggested above.

In particular, the regime continuum casts new light on the interplay among concepts of compliance, dispute avoidance and dispute resolution. For example, one might question the inclination to define behavior within regimes principally on an axis of compliance to noncompliance, which promotes the crystallization of disputes. Instead of defining disputes, one might refocus on strategies to enable the continuing development of a regime despite inevitable conflicts on particular questions within the broader issue-area.

As international lawyers, we of course value the stage in regime development during which formal legal norms emerge or are negotiated. But we also suggest that there is a role for international lawyers in articulating and promoting appropriate principles that can direct or shape the evolution of a regime toward those binding norms. The articulation of principles furthers two distinct, but overlapping, agendas. First, it may point to the need for a regime. Second, the principles may help to guide the evolution of the regime, both substantively and procedurally. Another goal of this paper is therefore to suggest how the principles of international ecosystem law discussed in our previous article may contribute to regime formation and development in the issue-area of shared freshwater resources. These principles, designed to promote an ecosystem orientation

\footnotetext{
${ }^{10}$ We have suggested that an ecosystem approach "requires consideration of whole systems rather than individual components" and that this, in turn, necessitates "management approaches that are broad-based in a spatial sense," as well as based on criteria for "human interaction with and use of the environment [that] respect the need for maintaining 'ecosystem integrity'." Brunnée \& Toope, supra note 1, at 55.

${ }^{11}$ For a useful definition of international institutions, see Robert O. Keohane, Neoliberal Institutionalism: A Perspective on World Politics, in InTERnational Institutions and STATE Power 1 (Robert O. Keohane ed., 1989). See also Oran R. Young, International Regimes: Toward a New Theory of Institutions, 39 WORLD POL. 104 (1986); Anne-Marie Slaughter Burley, International Law and International Relations Theory: A Dual Agenda, 87 AJIL 205, 220-26 (1993); and John K. Setear, An Iterative Perspective on Treaties: A Synthesis of International Relations Theory and International Law, 37 HARV. INT'L L.J. 139, 142-47 (1996).
} 
for international law, include the concepts of sustainable development, intergenerational equity and precaution. While remaining human focused in outlook, these three interrelated concepts introduce an ecological dimension, at least to the extent that, independently of interference with states' sovereign interests, development must respect limits defined by what the environment can sustain. In addition, ecosystem orientation requires principles that are broadly based in a spatial sense. Therefore, freshwater regimes should be built upon the drainage basin concept and the notion of common concern. ${ }^{12}$

We argue that regimes framed in the context of ecosystem-oriented concepts are the most likely to be effective, both in ensuring ecological balance and in preventing conflict over shared water resources. Obviously, our approach is not value neutral. The principles that we have articulated are rooted in assumptions related not only to efficacy, but to equity, transparency, justice and fairness. ${ }^{13}$ We acknowledge that the principles cannot always be applied in exactly the same fashion, given the diversity of contexts in which they may be relevant. ${ }^{14}$ Moreover, resource constraints, particularly within developing states, may make some of the principles difficult to implement in the short term. In such cases, we would argue that the very values we seek to promote in dealing with common concerns will demand the elaboration of common, but differentiated, obligations within societies and between states. ${ }^{15}$

In the first part of this paper, we set out our understanding of regime theory and how it relates to international law. We then suggest an approach to regime formation and elaboration that posits a continuum between contextual regimes and legal regimes. Finally, building upon the insights derived from regime theory and our argument concerning the emergence of international ecosystem law, we evaluate existing freshwater regimes and offer suggestions for a more sophisticated and effective elaboration of future regimes to promote environmental security. In particular, we argue that such regimes must emphasize avoidance of disputes and focus on implementation as a measure of effectiveness, moving away from a rhetoric of "enforcement" and deemphasizing mechanisms of dispute settlement. We also suggest that the framework-protocol approach, now well tested in international environmental law, is the most suitable model for the eventual legal consolidation of freshwater regimes, whether through treaty or custom. ${ }^{16}$

\section{INSIGHTS OF REGIME THEORY}

\section{Regime Theory and Intermational Law}

In a relatively early attempt to encapsulate the developing understanding of regime theory, Stephen Krasner posited the following definition, which has proven to be most influential. According to Krasner, regimes are

\footnotetext{
${ }^{12}$ For an extensive discussion, see Brunnée \& Toope, supra note 1 , at 65-75.

${ }^{13}$ These principles encapsulate and implement the legal values we seek to promote. Sustainable development, intergenerational equity, the precautionary principle and the concept of common concern are premised on a commitment to equity, fairness and justice. The drainage basin focus is rooted in a desire for transparency, as well as efficacy. Each of these values is also promoted in the approach to regime structuring we argue for in the text at and notes 91-96 infra. On the role of values in generating legal norms, see LON L. FULLER, THE MORALity OF LAW (rev. ed. 1969).

${ }^{14} \mathrm{We}$ are mindful that many of the proposals made in this paper may be perceived as of questionable immediate relevance to developing countries. For this reason, the third phase of our project is designed to test our assumptions and proposals in a setting involving developing countries sharing a freshwater resource in a conflictual context, the Nile Basin.

${ }^{15}$ See Brunnée \& Toope, supra note 1, at 73-74. On the origins of the concept of common, but differentiated, obligations and its connection to the concept of common concern, see Jutta Brunnée, A Conceptual Framework for an International Forests Convention: Customary Law and Emerging Principles, in GLOBAL FORESTS AND INTERNATIONAL ENVIRONMENTAL LAW 41, 60-61 (Canadian Council on International Law ed., 1996).

${ }^{16}$ The merits of various approaches to treaty making are exhaustively examined in ABRAM CHAYEs \& ANTONIA HaNDler Chayes, The New SOVEREIGNTY: CoMPlianCE WITH INTERNATIONAL REgulatory AgReEMENTS (1995). Our focus is broader in that we propose to examine regime formation along a continuum from contextual regimes to binding legal regimes.
} 
implicit or explicit principles, norms, rules, and decision-making procedures around which actors' expectations converge in a given area of international relations. Principles are beliefs of fact, causation, and rectitude. Norms are standards of behavior defined in terms of rights and obligations. Rules are specific prescriptions or proscriptions for action. Decision-making procedures are prevailing practices for making and implementing collective choice. ${ }^{17}$

This definition is not entirely satisfying from the perspective of the international lawyer. Many contemporary international regime theorists emphasize the influence of norms on the establishment of "negotiating frameworks" and in the coordination of "actor expectations." 18 Norms embedded in regimes emerge through the "fusion of power with legitimate social purpose," which is the genesis of political authority ${ }^{19}$ Within this political science framework, a norm can best be viewed merely as a "guide" to action that members of a regime are expected to perform under certain circumstances. ${ }^{20}$

The emphasis on negotiation and actor expectations certainly finds echoes in the literature of international legal theory, notably in the work of Myres McDougal and Harold Lasswell. For McDougal and Lasswell, legal normativity was a social process in which power was shaped and controlled through authoritative decision. Authoritative decision, in turn, was seen as resulting from "common expectations concerning authority with a higher degree of corroboration in actual operation.",21

From our perspective, a central difficulty with the McDougal and Lasswell approach, and with the way international regime theorists use the term "norm," is that it seems generic, a mere sociological description of collective expectations about proper behavior in a specific situation with given actors. This notion of norm almost completely melds law with politics. ${ }^{22}$ Atavistically, international lawyers seek out more precision, attempting to identify a concept of legal normativity distinct from sociologically observable behavior. ${ }^{23}$ But here we reach the international lawyer's central dilemma. For a law rooted extensively in custom, it is difficult to identify the distinctively legal element of normativity when the law itself is defined through the practice of the participants in the system. Law sounds like a coordination game in which actor expectations are assessed and a normative consensus emerges. Such a game seems focused on description, and perhaps prediction, but not prescription.

It is likely for this reason that the late twentieth century has been marked by an impetus toward the elaboration of explicit rules through negotiated treaties, and an emphasis on "enforcement" as the sine qua non for effectiveness. But these strategies to promote legal normativity often prove to be illusory. Because there is no global community in any meaningful sense, ${ }^{24}$ but only associations of states and other actors

\footnotetext{
${ }^{17}$ Stephen D. Krasner, Structural Causes and Regime Consequences: Regimes as Intervening Variables, in INTERNATional Regimes 1, 2 (Stephen D. Krasner ed., 1983).

${ }^{18}$ See, e.g., Robert O. Keohane, The Demand for International Regimes, 36 INT'L ORG. 325, 338-39 (1982); and Krasner, supra note 17.

${ }^{19}$ John Gerard Ruggie, International Regimes, Transactions, and Change: Embedded Liberalism in the Postwar Economic Order, 36 INT'L ORG. 379, 382 (1982).

${ }^{20}$ Oran R. Young, InTERnational CoOperation: Building Regimes for Natural Resources and the ENVIRONMENT, passim (1989).

${ }^{21}$ Myres S. McDougal \& Harold D. Lasswell, The Identification and Appraisal of Diverse Systems of Public Order, in 2 The Strategy of World ORder 45, 53 (Richard A. Falk \& Saul H. Mendlovitz eds., 1966) [hereinafter WORLD ORDER], quoted in FrIEDRICH KRATOCHWIL, RULES, NORMS, AND DECISIONS 194 (1989); see also HAROLD D. LASSWEll \& Myres S. MCDOugAL, JurisprudenCE FOR A FreE Society (1992). For useful commentaries on McDougal and Lasswell's work, see Slaughter Burley, supra note 11, at 209-11; and Michael Byers, Custom, Power and the Power of Rules: Customary International Law from an Interdisciplinary Perspective, 17 MICH. J. INT'L L. 109, 123-24 (1995).

${ }^{22}$ KRATOCHWIL, supra note 21 , at $196,200$.

${ }^{23}$ On this point, see also CHAYEs \& CHAYES, supra note 16 , at 112-18.

${ }^{24}$ See Phillip R. Trimble, International Law, World Order, and Critical Studies, 42 STAN. L. Rev. 811,816 (1990).
} 
for practical purposes ${ }^{25}$ in any given issue-area normative communities must first be imagined and nurtured. Binding norms typically emerge when a regime has moved along the continuum from mere coordination to at least a partial convergence of interests and values. For example, the processes of international negotiation leading to the conclusion of treaties are "often characterized by bargaining and coercive moves rather than by persuasion and by appeals to common standards, shared values, and accepted solutions." 26 Treaty rules that result from such trade-offs, where common interests and values have not been present, are unlikely to act as "causes" of behavior. Put most pointedly, this observation tends to undercut any theory of international law rooted solely in formal consent. States may very well consent to explicit formulations of rules that they do not intend to observe in practice. The plethora of environmental and human rights standards set out in innumerable conventions, many of which are breached on a daily basis, is sad testimony to this truth. Proponents of conventions will argue that the role of treaties that are constantly breached is not so much to provide binding norms as to create possible avenues for advocacy and education. ${ }^{27}$ But this explanation ironically supports the view that we will develop: rather than repositories of a definitive legal solution to shared problems, these treaties are nothing more than ungrounded, or at best nascent, regimes from which it is hoped that real solutions will emerge. Similarly, the penchant of some international lawyers for demanding "enforcement" of a supposed norm will often prove ineffective if there is no common acceptance of the norm's legitimacy.

It could be argued that these issues are not really concerned with the existence of norms, but with their effectiveness. In our view, the existence of norms remains a central challenge for international lawyers, one that can usefully be analyzed by building upon regime theory from perspectives of international law. While we are not satisfied by the tendency of regime theory to describe "norms" in merely sociological terms, one cannot address this concern, as many international lawyers have tended to do, simply by demanding more precision in the wording of rules or more enforcement. Rather, we may more usefully test legal normativity by asking questions about legitimacy, and shared interests and values. We will argue that norms that are not rooted in a normative community generating common standards of legitimation are not likely to prove to be binding legal norms at all.

Regime theory provides insights into the elaboration of "guides to action," which can be built upon by international lawyers seeking to identify, or dare we say generate, binding legal norms. Our central point is that regimes are not coextensive with "custom" per se. In fact, they are better seen as potential precursors to, or possibly incipient evidence of, emerging custom; alternatively, as the fertile ground for the elaboration of explicit treaty norms. Regimes as understood in international relations theory, because of their grounding in state practice, provide building blocks for the construction of more specific (and binding) legal regimes. We call these relatively informal and nonbinding regimes "contextual regimes," for they provide a setting in which binding normativity can emerge. ${ }^{28}$ This assertion, of course, is based on an assumption about the very nature

\footnotetext{
${ }^{25}$ See Michael OAkeshott, On Human Conduct 108-14, 119-21 (1975) (on civil and transactional associations, and practices).

${ }^{26}$ See KRATOCHWL, supra note 21 , at 254

${ }^{27}$ See Stephen J. Toope, The Convention on the Rights of the Child: Implications for Canada, in CHILDREN'S RIGHTS: A Comparative Perspective 33 (Michael D. A. Freeman ed., 1996); and Cynthia Price Cohen, Stuart N. Hart \& Susan M. Kosloske, The UN Convention on the Rights of the Child: Developing an Information Model, to Computerize the Monitoring of Treaty Compliance, 14 HUM. RTs. Q. 216, 220 (1992).

${ }^{28}$ We admit, however, that further normative elaboration is not inevitable, or necessarily desirable. Contextual regimes have independent value and should not be viewed as inchoate even if binding rules of law fail to emerge in certain settings.
} 
of "legal" norms, at least in the international context, an assumption that calls for elaboration.

We believe that international law is best envisioned as a form of practical reasoning. ${ }^{29}$ Because practical disputes can rarely be resolved by reference to pure logic, we agree with McDougal and Lasswell that settlement will occur only through processes of authoritative decision. But the authority of processes of legal decision cannot be treated as a purely instrumental question, depending largely upon the acceptance of outcomes, and here we part company with the New Haven School. Legal normativity, and this is one of its most distinctive features, is rooted in the pervasive interaction of ends and means. ${ }^{30}$ That is, many of the goals of law are inherent in its means: fairness and predictability, for example, are important process values, as well as important in the results. ${ }^{31}$ For that reason, legal norms are both constitutive and directive. They help to shape the relevant processes of authoritative decision, by establishing a vocabulary, the parameters of what "counts" as argument, and who can participate in the debate. These shared understandings of process emerge within contextual regimes where political legitimation has occurred. Legal norms also seek to guide behavior, but the effectiveness of the guidance results not from the ability to enforce the norm, but from the acceptance of decisions as authoritative. The authority emerges from the perceived legitimacy of the process of norm evolution (within a regime), as well as subsequent processes of application, and evaluation of the norm itself. ${ }^{32}$ Thus, norms will not be perceived as legitimate on the basis of process alone; external measures of value must also be applied, including tests of equality, transparency, justice and fairness. That is why we argue that ecosystem principles are crucial to the elaboration of effective and just freshwater regimes.

Regime theory can help us identify sources of persuasive authority and guide us in the development of processes of norm evolution and application that are likely to be perceived as legitimate. In addition, regime theory can assist us in reconceiving the effectiveness of legal norms in terms of implementation, which admits of the progressive evolution of norms, rather than enforcement, which tends to view normativity in more static terms as the direct application of fixed rules through force or the threat of force. A focus upon implementation, rather than enforcement, underscores the continuing need for assessments of legitimacy within formal and informal legal institutions, assessments we have described as essential to the emergence and progressive development of legal normativity. Furthermore, fidelity to an overarching institution, such as international law, is also generated by perceptions of legitimacy, which in turn can lead to the elaboration of specific norms through the acceptance of patterns of behavior as binding.

\section{Regime Building}

We have suggested how regime theory can help us understand legal normative evolution. Can it assist us in shaping particular legal regimes governing the use and conservation of shared freshwater resources?

\footnotetext{
${ }^{29}$ Stephen J. Toope, Confronting Indeterminacy: Challenges to International Legal Theory, 19 CAN. CoUNCIL INT'L L., Proc. 209, 211 (1990).

${ }^{30}$ Fuller, supra note 13 , passim, especially at 145-51.

${ }^{31}$ KRATOCHWIL, supra note 21 , at 59.

${ }^{32}$ Thomas Franck articulated a similar argument in terms of fairness as the central factor in explaining normativity and promoting norm compliance. ThOMAS M. Franck, FAIRness in InTERnational LAW AND INSTITUTIONS 23-24 (1995) (arguing that fairness derives its power from its two key components, legitimacy and justice; a legal norm invites compliance to the extent that it balances the need for "order"-legitimacy resulting from the "right process"- and the need for "change"-rules reflecting distributive justice). See also CHAyes \& ChAyes, supra note 16, at 127-34. For a useful discussion of norm legitimation, see Roderick A. Macdonald, Office Politics, 40 U. TORONTO L.J. 419 (1990).
} 
Regimes are, at the outset, "social institutions" or "recognized patterns of behavior or practice around which expectations converge,"33 or what we have called contextual regimes. Over time, and with a growing sense of legitimacy, regimes can harden and binding legal norms may emerge ${ }^{34}$ Because regimes are rooted in practice, they can arise spontaneously or through processes of negotiation. ${ }^{35}$ One should not overemphasize, however, the extent to which regimes are likely to be negotiated and renegotiated: "it is exceedingly difficult to bring about planned or guided changes in complex institutions of this sort. ${ }^{, 36}$ Indeed, once a regime is established through practice and a convergence of expectations around the practice, the regime may assume a life of its own: the regime expectations may persist even after the causes that prompted its evolution have changed, and the regime may come to influence and alter the causal variables that initially gave rise to it. ${ }^{37}$ In this way, regimes may influence the perception and exercise of power, and the evaluations of interest and values that affect states' determination to act. Nevertheless, we would not go so far as to suggest that regimes are immune to guided change. Like all social institutions, they are at most relatively autonomous. It may be precisely at the intersection of regime theory and international law that such guidance can take place. Through the elaboration of substantive principles and the shaping of processes of coordination, international law can affect the development of a regime within a given issue-area.

Because regimes arise through the coordination of expectations emerging from relatively consistent practice, they tend to facilitate further cooperation. But cooperation is not necessarily morally positive; it may not even be neutral. Regimes may tend to downplay divergent interests, institutionalizing "inequalities." ${ }^{38}$ Moreover, the coordination of behavior and expectation will not invariably be entirely voluntary, even in the absence of any binding legal norm. Power differentials may shape the evolution of a regime that will remain a place of "tension in which actors struggle to define the regime and the space it orders." 39 This tension is most obvious in the analysis positing that regimes are most likely to arise when promoted by a powerful hegemon. ${ }^{40}$ Even if one rejects the emphasis on hegemony as a condition for regime formation, ${ }^{41}$ one should not underestimate the importance of power in molding and guiding regimes. ${ }^{42}$

While we accept that power differentials and the pursuit of advantage do shape state behavior, we do not believe that power is the sole variable that must be considered. ${ }^{43}$

\footnotetext{
${ }^{33}$ Oran R. Young, Regime Dynamics: The Rise and Fall of International Regimes, 36 INT'L ORG. 277,277 (1982). See also Krasner, supra note 17, at 2.

${ }^{34}$ See Keohane, supra note 18.

${ }^{35}$ See Eyal Benvenisti, Collective Action in the Utilization of Shared Freshwater: The Challenges of International Water Resources Law, 90 AJIL 384, 400-04 (1996).

${ }^{36}$ Young, supra note 33, at 280.

${ }^{37}$ Stephen D. Krasner, Regimes and the Limits of Realism: Regimes as Autonomous Variables, 36 INT'L ORG. 497, 500 (1982).

${ }^{38}$ Stephan Haggard \& Beth A. Simmons, Theories of International Regimes, 41 INT'L ORG. 492,509 (1987).

${ }^{39}$ James F. Keeley, Toward a Foucauldian Analysis of International Regimes, 44 INT'L ORG. 83, 98-99 (1990).

${ }^{40}$ See, e.g., Charles Lipson, The Transformation of Trade: The Sources and Effects of Regime Change, 36 INT'L ORG. 417, 437 (1982).

${ }^{41}$ The explanatory power of a hegemonic theory has been convincingly questioned by Duncan Snidal, The Limits of Hegemonic Stability Theory, 39 INT'L ORG. 579 (1985); Peter M. Haas, Do Regimes Matter? Epistemic Communities and Mediterranean Pollution Control, 43 INT'L ORG. 377 (1989); and even by a foremost proponent of rational choice theory, of which hegemonic regime stability has traditionally been a part, ROBERT O. KeOHANe, AfTER Hegemony (1984).

${ }^{42}$ See the thoughtful discussion of the role of power in international relations and international law in Byers, supra note 21, at 112-27.

${ }^{43}$ Slaughter Burley, supra note 11, especially at 207-37, has comprehensively studied current debates among international relations theorists and how they may affect our understanding of international law. See also Kenneth W. Abbott, Modern International Relations Theory: A Prospectus for International Lawyers, 14 YALE J. INT'L L. 335 (1989).
} 
Nor are "interests" of states an all-encompassing explanation for behavior. ${ }^{44}$ We believe that values have some explanatory power, ${ }^{45}$ that they can be identified and fostered through regimes, and that they can shape regimes. In trying to understand how states will act, it is useful to consider all three variables: power, interest and values. This analysis links directly to our understanding of normative evolution, that only a combination of legitimated process and value-laden substantive outcomes will generate truly binding legal norms.

The most explicitly voluntarist version of regime theory, one that highlights the role values play in the emergence and development of regimes, focuses on the contribution of "communities of shared knowledge," or "epistemic communities." While regimes may emerge and even develop without the impetus of epistemic communities ${ }^{46}$ we agree with Oran Young and Gail Osherenko that a "transnational network of scientists and policy makers" may influence regime formation, particularly in identifying relevant policy options. ${ }^{47}$ It might even be argued that international lawyers themselves form something akin to an epistemic community, because they promote values through specific principles, such as the ecosystem principles posited in this paper, which can guide the evolution of regimes and ultimately gain normative significance. ${ }^{48}$ Furthermore, in the words of a leading proponent of the epistemic community theory: "if a group with a common perspective is able to acquire and sustain control over a substantive policy domain, the associated regime will become stronger and countries will comply with it." 49 This version of regime theory assumes that regimes are best viewed as institutions, rather than as collections of static rules; the epistemic community serves as a means for "international learning that produce[s] convergent state policies." ${ }^{50}$ Basing itself on common understandings of fact and increasingly overlapping values verified through the conduct

\footnotetext{
${ }^{44}$ First, the notion that states can actually identify and articulate coherent interests is a rationalist assumption that is not empirically demonstrable. In any event, even within a given state, interests may be diverse and incommensurate. Second, as Young and Osherenko have argued: "Advocates of transcendent goals may . . . persuade policy makers that what promotes the common good serves a state's national interests." ORAN R. Young \& Gail Osherenko, Polar Politics: Creating International Environmental Regimes 240 (1993). Third, as regimes form and evolve, common interests are identified and promoted, which allows the regime to provide a counterweight to individual assessments of state interest. States may also follow specific rules when there is a long-term interest in the maintenance of the rule of law in the international milieu.

${ }^{45}$ See Martti Koskenniemi, From Apology to Utopia 8 (1989); Young \& Osherenko, supra note 44; and FrANCK, supra note 32, at 24.

${ }^{46}$ Epistemic communities will not coalesce in every issue-area. Governments may actively discourage participation in transnational networks and, given the resource constraints of many developing societies, it may not be possible for inclusive networks to form and operate. Even in the developed world, cuts in public spending may hamstring nascent, and even well-established, epistemic communities. In June 1996, the Canada-U.S. International Joint Commission complained that budget cuts in both countries put at risk many of the improvements to Great Lakes water quality, and stressed that their effect on research and advocacy organizations would be to hamper further progress. See International Joint Commission, Eighth Biennial Report under the Great Lakes Water Quality Agreement of 1978, Executive Summary (1996) 〈http://www.greatlakes.net:2200/ partners/IJC/html/8bien/repeng/html .

${ }^{47}$ See Young \& OSHERENKO, supra note 44, at 245.

${ }^{48}$ Implicit in this suggestion is the view that epistemic communities are not limited to "scientific" or "technological" groupings. Although most case studies of epistemic communities have focused on this type of expert group, proponents of the theory have acknowledged that "policy makers" could form an epistemic community. See id. We suggest that international lawyers can be equated with policy makers for these purposes. One need only consider the contributions of the International Law Association (ILA) and the International Law Commission (ILC) to the evolution of freshwater regimes, or the efforts of the Commission on Environmental Law of the World Conservation Union (IUCN) developing an International Covenant on Environment and Development (1995), discussed in detail at $\langle$ http://www.iucn.org/themes/law/covenant.html $\rangle$.

${ }^{49}$ Haas, supra note 41 , at 380 .

${ }^{50} \mathrm{Id}$. at 377 . Given the posited role of influence, the idea of the epistemic community is closely related to the broader argument of the power of elites to create and shape regimes. See Donald J. Puchala \& Raymond F. Hopkins, International Regimes: Lessons from Inductive Analysis, 36 INT'L ORG. 245, 247 (1982); see also Myres S. McDougal \& Harold D. Lasswell, Some Basic Theoretical Concepts about International Law: A Policy-Oriented Framework of Inquiry, in WORLD ORDER, supra note 21, at 116, 129 (on elites and legal normativity).
} 
of research, the epistemic community develops commensurate views on how best to address a given issue-area and promotes those views through domestic and international policy discussions. ${ }^{51}$ State governments come to coordinate their practices under the influence of the epistemic community.

We acknowledge that the influence of epistemic communities is not inevitable. Government officials will not necessarily heed the suggestions of scientific and policy elites, partly out of lack of understanding, partly out of the need to balance various domestic interests, and partly out of a desire to retain control.$^{52}$ Furthermore, the very notion of expert elites' defining policy options may be perceived as undemocratic and opaque. ${ }^{53}$ However, given the diversity and horizontal nature of international society, some reliance on elite communities for policy development and normative evolution is unavoidable. Many observers have emphasized the need for "leadership" and the mobilization of elites. ${ }^{54}$ In any event, positing an influential role for epistemic communities need not imply a lack of transparency, for two reasons. First, in many cases-we would argue in most-nongovernmental organizations (NGOs) should be able to participate in the relevant epistemic community. ${ }^{55}$ Some NGOs have themselves become transnational expert communities. ${ }^{56}$ Second, the role of epistemic communities in promoting normative evolution will always remain subservient to the ultimate decision-making authority of national governments. To the extent that such governments are themselves transparent, democratic participation will be possible. Many governments do not allow effective public participation, but this sad reality is not made worse by the involvement of epistemic communities in the shaping of policy. Indeed, the transnational aspect of epistemic communities may sometimes promote such transparency because the participation of domestic elites in international dialogue can reinforce the power of opposition groups. ${ }^{57}$

We take the position that the types of regimes described above, particularly regimes that evolve spontaneously and largely voluntarily, can serve as the foundation for formal legal regimes. It is at this point that the interaction between regime theory and international law becomes explicit. In the most obvious sense, informal regimes can open up possibilities for effective institutional bargaining, which can lead to legal regimes and formal structures of cooperation..$^{58}$ Robert Keohane has argued that the tendency of regimes to lead to more precise agreements is at the heart of their appeal:

[A] major function of regimes is to facilitate the making of specific agreements on matters of substantive significance within the issue-area covered by the regime. International regimes help to make governments' expectations consistent with one another. Regimes are developed in part because actors in world politics believe that with such arrangements they will be able to make mutually beneficial agreements that would otherwise be difficult or impossible to attain. ${ }^{59}$

\footnotetext{
${ }^{51}$ Haas, supra note 41 , at 384 .

${ }^{52}$ Lynton K. Caldwell, Between Two Worlds: Science, the Environmental Movement, and Policy Cholce 23 (1990); Myron L. Scott, Two Models for International Environmental Cooperation, 22 EnVTL. L. 334, 354 (1992) (book review).

${ }^{53}$ Tony Brenton, The Greening of Machiavelli 256 (1994).

${ }^{54}$ See Lasswell \& MCDougal, supra note 21; Young \& Osherenko, supra note 44, at 234; Oran R. Young, The politics of international regime formation: managing natural resources and the environment, 43 INT'L ORG. 349, 355 (1989); and Harold K. Jacobson \& Edith Brown Weiss, Strengthening Compliance with International Environmental Accords: Preliminary Observations from a Collaborative Project, 1 GLOBAL GOVERNANCE 119, 126 (1995).

${ }^{55}$ On NGOs and the implementation of treaty norms, see Jacobson \& Weiss, supra note 54, at 129; see also CHAYES \& CHAYES, supra note 16 , at 250-70.

${ }^{56}$ Consider the influential role of NGOs as diverse as the IUCN and the World Wildlife Fund.

57 See SuzAnne Ogden, ChinA's UnResolved Issues (1989); and Jacobson \& Weiss, supra note 54, at 142.

${ }^{58}$ Young, supra note 54, at 366-73.

${ }^{59}$ Keohane, supra note 18 , at 334 .
} 
We argue that regimes are instrumentally useful from an international lawyer's perspective for other reasons as well, reasons that are often overlooked in the literature of regime theory. Regimes, as the coordination of state practice and generator of patterns of expectation, can harden into binding custom. In this sense, regimes can be seen as incipient custom or as normativity on the verge of "crystallization." Binding norms may therefore emerge not merely from explicit negotiation within the context of the regime, but from increasingly rigid patterns of expectation that solidify into opinio juris. The regime can then be viewed, ex post facto, as the pattern of "confidence-building measures" that allowed cooperative behavior, or at least the coordination of diverse interests, to evolve and legal norms to be created, either expressly through treaty, or implicitly through custom.

If contextual regimes are linked to "confidence-building measures," as we have just suggested, a further connection becomes apparent. In interstate negotiations leading to the elaboration of institutional structures affecting shared freshwater resources, more and more emphasis is placed on processes of dispute avoidance. These processes, which will be discussed at length below, ${ }^{60}$ may turn out to be but another way of describing the contextual regime (sharing of information, prior notification, intrusive verification) that permits further normative elaboration. Lawyers tend to talk about confidence building and dispute avoidance in structural terms, through reference to "measures" and "mechanisms"; the structural analysis of international relations scholars is more commonly described in terms of regimes. But there is a strong connection between the two types of discourse, and they will often be attempts to describe the same observable facts.

It is worth reiterating that international lawyers should pay attention to regime analysis for the new insights it can provide into the value of processes of coordination that are not immediately directed toward the definition of substantive norms. Premature formulation of explicit rules may create a false sense of "solution." The evolution of a regime will open up possibilities for legal entrepreneurship. ${ }^{61}$ In the context of increasingly commensurate perspectives and shared practices among states, the power of practical reasoning is enhanced and the international lawyer is presented with opportunities for imaginative normative design.$^{62}$ The key, of course, will be to design and promote norms and processes that continue to be viewed as legitimate, embodying the legal values of justice, fairness, equality and transparency. We have already quoted John Ruggie's suggestion that "political authority represents a fusion of power with legitimate social purpose." ${ }^{\prime 3}$ We can now move a step forward to argue that legal authority represents a fusion of legitimate social purpose and value-laden processes of investigation, decision making and implementation.

We will therefore use the notion of the regime in two distinct manners while considering shared freshwater resources: first, to signify the evolving context of policy discourse and political exchange out of which may grow specific negotiations leading to framework agreements and binding customary norms. The relevant regime may be informal or formal. It may emerge purely from patterns of reciprocity between states, or from the persuasive authority of epistemic communities. Such contextual regimes may have some institutional focus or be "virtual," to adopt the new jargon. In either case, principles and nonbinding norms of behavior may emerge that govern issues of both procedure (the rules of the game) and substance (some agreed-upon outcomes).

\footnotetext{
${ }^{60}$ See text at and notes 105-21 infra.

${ }^{61}$ This notion is adapted from Young, supra note 54, at 355.

${ }^{62}$ See also CHAYES \& CHAYES, supra note 16, at 122-23 (pointing to the importance of dynamic normative processes)

${ }^{63}$ Ruggie, supra note 19 , at 382.
} 
The second meaning of the term regime is more precise: the set of commitments that emerge from negotiations and often result in framework agreements, which are embedded in the more fluid regime context described immediately above. This usage of regime makes explicit our view that regimes are not static points encompassing a particular level of normativity but are better seen as a bridge from the most simple attempts to find some policy commonality in an issue-area, to binding legal norms shaping the behavior of states within the same issue-area. This notion of bridging toward binding norms distinguishes our use of regime theory from that which is typically proposed by international relations scholars. Ultimately, as international lawyers, we seek a relative autonomy for legal norms, but we acknowledge that such norms are most likely to evolve from preexisting contextual regimes.

\section{REgIME THEORY AND INTERNATIONAL ECOSYSTEM LAW}

We suggested earlier that international law has traditionally considered environmental degradation as legally relevant only when it constituted interference with a state's sovereign interest. To this day, two customary rules rooted in this approach remain the cornerstones of the law governing transboundary freshwater resources. The first is the principle that a state's sovereign right to exploit its natural resources is limited only by the obligation not to cause significant environmental harm in other states. The other is that riparian nations must equitably share the beneficial uses of freshwater resources straddling their territories. ${ }^{64}$ In the following pages, we illustrate the extent to which this conceptual preoccupation with territorial and sovereign interests has shaped freshwater regimes in ways that make them unsuited to promoting environmental security. It underpins the sectoral approaches, focused on individual areas of resource use, and the competitive approaches to allocation of uses adopted by most early freshwater regimes.

\section{Early Models of Freshwater Regimes}

Sectoral approaches. The majority of early freshwater regimes were sectoral in one or more respects. ${ }^{65}$ Most dealt only with individual issues that had emerged as demanding coordination among the states sharing a river or lake. For example, the earliest agreements sought to govern activities such as navigation and fishing. ${ }^{66}$ Progressively, matters such as apportionment of waters, flood control, irrigation and energy generation took over as primary concerns in treaty making. ${ }^{67}$ When, environmental protection was recog-

\footnotetext{
${ }^{64}$ In Brunnée \& Toope, supra note 1, at 53-57, we argued that these concepts cannot ensure environmental security and must therefore be complemented by or reinterpreted in light of the ecosystem-oriented principles outlined above.

${ }_{65}^{65}$ See Lucius Caflisch, The Law of International Waterways in Its Institutional Aspects, in IM DIENSTE DER GEMEINSCHAFT-FESTSCHRIFT FÜr DIETRICH SCHINDLER ZUM 65. GeburTSTAG 21, 27-30 (Walter Haller et al. eds., 1989); Joseph W. Dellapenna, Treaties as Instruments for Managing Internationally-Shared Water Resources: Restricted Sovereignty vs. Community of Property, 26 CASE W. RES. J. INT'L L. 27, 42-47 (1994).

${ }^{66}$ On navigation, see, e.g., Congress of Vienna, Final Act, June 9, 1815, Art. 32, Annex 16B, 64 Consol. TS 454; Revised Convention on the Navigation of the Rhine, Oct. 17, 1868, 138 Consol. TS 167; and Strasbourg Convention to Amend the Revised Convention for Rhine Navigation, Nov. 20, 1963, 1967 Gr. Brit. TS No. 66; Additional Protocol to the Revised Convention on Navigation on the Rhine, Oct. 25, 1972, 1975 Gr. Brit. TS No. 86; Convention Concerning the Regime of Navigation on the Danube, Aug. 18, 1948, 33 UNTS 196. On fishing, see, e.g., Convention Concerning Fishing in the Rhine, Dec. 9, 1869, Baden-Switz., reprinted in 9 International Protection of the Environment-Treaties and Related Documents 4695 (Bernd Rüster \& Bruno Simma eds., 1977) [hereinafter Rüster \& Simma]; Convention Regulating Fisheries in Boundary Waters, Nov. 5, 1892, Luxembourg-Prussia, reprinted in id. at 4750; Convention Concerning Fishing in the Waters of the Danube, Jan. 29, 1958, United Nations, Legislative Texts and Treaty Provisions, UN Doc. ST/LEG/SER.B/12, at 427 (1963).

${ }^{67}$ The following agreements, inter alia, focus primarily on apportionment of water: Convention Providing for the Equitable Distribution of the Waters of the Rio Grande for Irrigation Purposes, May 21, 1906, U.S.Mex., 34 Stat. 2953 (apportionment); Treaty Relating to the Utilization of Waters of the Colorado and Tijuana Rivers and of the Rio Grande, Nov. 14, 1944, U.S.-Mex., 59 Stat. 1219, 3 UNTS 313 (apportionment and flood
} 
nized as a transboundary concern, treaty making again followed the selective pattern and tended to target individual pollutants or types of activities generating pollution. ${ }^{68}$ Of course, in this latter regard, the development of freshwater regimes differed little from the sectoral approaches generally preferred during the first wave of environmental protection efforts, both domestic and international. In addition to selectivity as to types of pollutants or activities, agreements commonly were selective as to the environmental medium protected. In part for this reason, then, but also because of the riparian states' desire to minimize any loss of sovereignty, most freshwater agreements were narrow in geographic scope. In particular, many of the early agreements encompassed only the watercourse per se, rather than the drainage basin in which the river or lake is located, largely ignoring the interaction between water and other environmental media such as air and land. ${ }^{69}$ Other agreements, in equally arbitrary fashion from an environmental standpoint, focused on portions of a river, lake or basin. ${ }^{70}$

Competitive and use-oriented approaches. Substantively, the purpose of many agreements was limited to enshrining a more or less rigid formula for the allocation of water uses. ${ }^{71}$ At times, the riparians were so intent on retaining a maximum of sovereign control that the allocation agreement did not even allow for adaptation to changing circumstances or needs, but permitted only the negotiation of a new agreement. ${ }^{72}$ To the extent that agreements did include general substantive principles, these tended to concern the balancing of competing sovereign interests in resource use, rather than common environmental interests. Again, this approach partly reflects a particular stage in the development of what is understood today as international environmental law. ${ }^{73}$ However, the norms governing international rivers also appear to have been seen as distinct from those governing international environmental relations more generally, and therefore as legitimately focused on resource use. ${ }^{74}$ Consequently, as suggested above, the principle limiting water use by one riparian only where it causes significant transboundary harm and

control) [hereinafter Colorado Treaty]; Agreement for the Full Utilization of the Nile Waters, Nov. 8, 1959, U. Arab Rep.-Sudan, 453 UNTS 51 (apportionment) [hereinafter Nile Agreement]; Indus Waters Treaty, Sept. 19, 1960, India-Pak., 419 UNTS 125 (apportionment and flood control); Interim Agreement on Sharing of the Ganges' Waters, Nov. 5, 1977, India-Bangladesh, reprinted in 17 ILM 103 (1978) (apportionment) [hereinafter Ganges Agreement]. For an agreement focused primarily on hydroelectricity, see Agreement on Paraná River Projects, Oct. 19, 1979, Arg.-Brazil-Para., reprinted in 19 ILM 615 (1980) [hereinafter Paraná River Agreement].

${ }_{68}^{6 e e}$, e.g., Convention on the Protection of the Rhine against Chemical Pollution, Dec. 3, 1976, 1124 UNTS 375, reprinted in 16 ILM 242 (1977) [hereinafter Rhine Chemical Convention]; and Convention on the Protection of the Rhine against Pollution by Chlorides, Dec. 3, 1976, reprinted in 16 ILM at 265 [hereinafter Rhine Chlorides Convention].

${ }^{69}$ For example, the Treaty Relating to Boundary Waters and Questions Arising along the Boundary, Jan. 11, 1909, U.S.-Can., 36 Stat. 2448 [hereinafter Boundary Waters Treaty], focused only on physical watercourses and covered only waters straddling the boundary, explicitly excluding border-crossing waters. See also Nile Agreement, Indus Waters Treaty, Ganges Agreement, and Paraná River Agreement, all supra note 67.

${ }^{70}$ For example, only portions of the relevant rivers or river basins are covered by the Colorado Treaty, Nile Agreement, and Ganges Agreement, all supra note 67.

${ }_{71}$ See, e.g., Colorado Treaty, supra note 67, Art. 10; Indus Waters Treaty, supra note 67, Arts. II, III and Annexes B, C, D; Nile Agreement, supra note 67, Art. I; Ganges Agreement, supra note 67, Art. II.

${ }^{72}$ See, e.g., Nile Agreement, supra note 67, Art. I (treating Egypt's and Sudan's allocations as “established rights"). By contrast, the Colorado Treaty, supra note 67, Arts. 2, 24, 25, allows for adjustment through the device of "minutes" adopted in the International and Boundary Water Commission; and the Ganges Agreement, supra note 67 , Art. XIII, made provision for periodic review of the entire treaty.

${ }^{73}$ See Brunnée \& Toope, supra note 1, at 53-54.

${ }^{74}$ This is reflected in the titles of the most influential efforts to develop generally accepted principles of international water law: the ILA Helsinki Rules on the Uses of Waters of International Rivers, 52 ILA, CONFERENCE REPORT 484 (1966); and the ILC draft articles on the law of the non-navigational uses of international watercourses, Report of the International Law Commission on the work of its forty-sixth session, UN GAOR, 49th Sess., Supp. No. 10, at 197, UN Doc. A/49/10 (1994) [hereinafter ILC 1994]. It is remarkable in itself that such work on non-navigational uses did not begin until the 1960s. See R. K. Paisley \& T. L. McDaniels, International Water Law, Acceptable Pollution Risk and the Tatshenshini River, 35 NAT. RESOURCES J. 111, 118 (1995). 
the principle of equitable utilization remained, explicitly or implicitly, the cornerstones of most freshwater agreements. ${ }^{75}$

This competitive approach also accounts for the narrow areas of procedural cooperation carved out by many freshwater agreements. Information exchange, notification and consultation regarding planned activities, and early-warning provisions, often related only to a given agreement's specific issue-area and were intended to enable parties to comply with substantive provisions such as those prohibiting significant harm or requiring equitable utilization. ${ }^{76}$

Despite the long history of international commissions for shared freshwater resources ${ }^{77}$ riparian states' careful guarding of their sovereign rights is also evident in the creation of these institutions. Among the numerous such commissions in existence today, many continue to have a very narrow and technical focus or lack significant powers altogether. ${ }^{78}$ To date, although long advocated, ${ }^{79}$ no broad move to institutional structures with significant original jurisdiction or powers for joint management of a shared water resource has been made. However, as will be discussed below, such a move would not necessarily promote effective regime building. ${ }^{80}$ Indeed, water commissions have been perceived as most useful in offering a forum for discussion and serving as clearinghouses. ${ }^{81}$ These commissions may therefore take on the role of epistemic communities in identifying common issues and positing possible policy responses.

Finally, the traditional emphasis on competing sovereign rights also manifested itself in compliance issues. To the extent that noncompliance or disagreements were contem-

\footnotetext{
${ }^{75}$ See Brunnée \& Toope, supra note 1, at 53-54. For a comprehensive list of agreements incorporating the "no significant (appreciable) harm" rule, see Report of the International Law Commission on the work of its fortieth session, [1988] 2 Y.B. Int'l L. Comm'n 36, UN Doc. A/CN.4/SER.A/1988/Add.1(Part 2). For a comprehensive review of agreements reflecting the equitable utilization principle, see Stephen C. McCaffrey, Second Report on the Law of the Non-Navigational Uses of International Watercourses, [1986] 2 Y.B. Int'l L. Comm'n, pt. 1, at 87, 103, UN Doc. A/CN.4/SER.A/1986/Add.1(Part 1).

${ }^{76}$ See Patricia W. Birnie \& Alan E. Boyle, International LaW and the Environment $234-40$ (1992).

${ }^{77}$ See, e.g., the U.S.-Canada International Joint Commission (IJC) established by the 1909 Boundary Waters Treaty, supra note 69. For an overview of existing institutions, see Stephen C. McCaffrey, Sixth Report on the Law of the Non-Navigational Uses of International Watercourses, [1990] 2 Y.B. Int'l L. Comm'n, pt. 1, at 41, 42-52, UN Doc. A/CN.4/SER.A/1990/Add.1(Part 1) [hereinafter McCaffrey, Sixth Report].

${ }^{78}$ Although a caveat as to the diversity of organizational structures and circumstances is usually registered, the literature contains a variety of classifications of watercourse organizations. For example, Radosevich distinguishes five basic features: (1) geographic jurisdiction (e.g., national boundaries, drainage basin); (2) form (informal, formal, autonomous); (3) duration (temporary, fixed term, permanent); (4) membership (bipartite, multipartite, including all riparians); and (5) subject matter (traditional issues, e.g., navigation, flood control, or development issues, e.g., planning allocation, optimum use). He suggests that institutional functions can range from negotiation to implementation. See George E. Radosevich, Implementation: Joint Institutional Management and Remedies in Domestic Tribunals (Articles 26-28, 30-32), 3 Colo. J. INT'L ENVTL. L. \& Pol'y 261, 262 (1992). In a 1992 study, Caponera concludes that the most common features of watercourse organizations are (1) recommendatory and advisory, as opposed to executive, powers; (2) indefinite or long duration, facilitating adaptation to change and new requirements; (3) authority to undertake or coordinate studies and investigations, leading to recommendations; (4) technical expertise of secretariat staff, preventing domination of political influence, which is concentrated at the commissioners' level; (5) permanent headquarters and diplomatic immunity for commission and secretariat staff; (6) judiciary powers to settle disputes, and to decide on apportionment issues and other matters. See DANTE CAPONERA, PRINCIPLes of WATER LAW AND ADMINISTRATION 237 (1992). Caflisch develops a "typology of institutional mechanisms" that distinguishes (1) structure and composition (one main, usually single-purpose, body as opposed to hierarchically structured entities with several organs; agencies consisting of different national sections or one joint unit); (2) functions (forum for negotiations; planning, decision-making and implementation powers; single and multipurpose); and (3) legal status. See Caflisch, supra note 65, at 23-26.

${ }^{79}$ For example, in its 1911 resolution, "International Regulations regarding the Use of International Watercourses," quoted in 24 ANNUAIRE DE L'INSTITUT DE DROIT INTERNATIONAL 365-67 (1991), the Institut recommended "that the interested States appoint permanent joint commissions, which shall render decisions, or at least shall give their opinion, when . . . serious consequences might result in that part of the stream situated in the territory of [another] State."

${ }^{80}$ See text at and notes 99-101 infra.

${ }^{81}$ See BIRNIE \& Boyle, supra note 76, at 241.
} 
plated at all, they tended to be conceptualized as issues of treaty interpretation or potential breaches of treaty obligations, and thus as cases for formal dispute resolution, typically involving a stepped procedure leading up to arbitration or adjudication. ${ }^{82}$

\section{New Perspectives from International Ecosystem Law and Regime Theory}

Shortcomings of the older model regimes. An analysis of the older generation of freshwater agreements from the vantage points of international ecosystem law and regime theory suggests that, apart from some notable exceptions, ${ }^{83}$ they are ill-suited to ensuring environmental security.

From the perspective of international ecosystem law, the principal shortcoming is the narrow focus of most agreements. Although they may have met the perceived needs of the time, sectoral approaches have been outpaced by a growing understanding of the interaction between different components of an ecosystem and between different environmental concerns. ${ }^{84}$ An exclusively sectoral approach, particularly when combined with rigid allocation arrangements, cannot promote environmental security. New issues that an agreement does not address or even anticipate inevitably arise. Because a sectoral agreement's specific concern is embedded in and affected by a larger ecosystem, the agreement may not even prove successful in achieving its narrow goals. Moreover, its effectiveness may ultimately be reduced by the spillover of conflicts relating to issues not covered by the agreement.

These difficulties are exacerbated if the treaty is rooted primarily in a competitive, rather than a cooperative, paradigm, as when the focus is on competing uses of the resource. Even when the agreement incorporates general principles such as the "no significant harm" and "equitable allocation" rules, environmental and ecosystem interests remain subordinated to the balancing of competing sovereign interests. Not only are these principles incapable of promoting environmental security; ${ }^{85}$ they also fail to take advantage of the momentum that could be gained from principles built in accordance with common environmental interests. ${ }^{86}$ Similarly, procedural obligations of riparian states or institutional structures defined by a narrow and use-oriented substantive framework tend to deprive the agreement of the flexibility to adapt to new concerns or to evolve in tandem with a growing understanding of ecosystem needs. ${ }^{87}$

From the perspective of regime theory, and particularly of our understanding of regime formation as moving along a continuum from contextual to binding regimes, the older sectoral approaches were not effective. In emphasizing the elaboration of substantive norms from the outset, they represented static attempts to "regulate" without

\footnotetext{
${ }^{82}$ Some of the older agreements are altogether silent on the issue, e.g., the Nile Agreement, supra note 67. Some agreements use existing water commissions in the resolution of disputes, such as those involving the U.S.-Canada IJC, which was originally vested with investigative and arbitral functions by the Boundary Waters Treaty, supra note 69, Arts. IX, X; see also the role of the Permanent Indus Commission envisaged in the Indus Waters Treaty, supra note 67, Art. IX; and the Ganges Agreement, supra note 67, Art. VII. The most common approach appears to be to provide for highly formal procedures, running the spectrum from consultation and negotiation to international arbitration or adjudication. See McCaffrey, Sixth Report, supra note 77, at $66-75$.

${ }^{83}$ In particular, the 1909 Boundary Waters Treaty, supra note 69 , which proved sufficiently flexible to be adapted to new concerns, ultimately spawning innovative approaches such as those developed under the Great Lakes Water Quality Agreements. See text at and notes 157-70 infra.

${ }^{84}$ With respect to the requirements of an ecosystem approach, see text at note 12 supra.

${ }^{85}$ See Brunnée \& Toope, supra note 1 , at 53-54.

${ }^{86}$ See Benvenisti, supra note 35 , at 400 .

${ }^{87}$ In note 83 supra, we noted that the 1909 Boundary Waters Treaty appears to contradict this assertion by having spawned the Great Lakes Water Quality Agreements. However, the very fact that the later Agreements came to be perceived as necessary in the 1970 s and moved far beyond the narrow parameters of the original Treaty, in response to the recognized need for a more broadly based and ecosystem-oriented framework, tends to support our argument. See also text at and notes 158-70 infra.
} 
necessarily seeking to foster further cooperation. ${ }^{88}$ In a sense, these agreements were the products of what we previously described as the international lawyer's instinct to generate seemingly binding norms, rather than regimes that may be facilitative initially, but can help to promote real normativity in the longer term. The older treaties reflect these problems, as they tended to polarize positions and result in normative stagnation. ${ }^{89}$

In addition, the preoccupation with individual water problems prevented the sectoral agreements from taking advantage of the dynamic potential of more broadly based regimes to allow successes on one question to offset failures or carry forward stalled processes on others. The dynamic forces of regime formation were further hampered by the narrow ambit of procedural cooperation and the carefully defined mandates of institutions, limiting the room for epistemic communities to evolve and influence practice under the agreement. Finally, when agreements provided for dispute resolution procedures culminating in reference to an international tribunal, those mechanisms remained largely unused-a phenomenon to be examined in greater detail below. ${ }^{90}$ The sectoral approaches therefore constrained the development of effective regimes and precluded the elaboration of an ecosystem perspective.

The need for ecosystem-oriented regime building. We argued in our earlier paper that international environmental law, to be more effective in promoting environmental security, must evolve from a system based on competing sovereign interests into "international ecosystem law." ${ }^{\prime 11}$ We argued further that shared freshwater resources must be included in this evolution and we offered six conclusions as to the path this evolution ought to follow. $^{92}$

First, environmental security can be ensured only by legal regimes that extend beyond the water resource to encompass the entire ecosystem. The scope of rights and obligations must be defined, at least in part, by the ambit and needs of the ecosystem. A regime should encompass all states whose activities can affect or be affected by the water resource and the drainage basin must therefore be used as its geographical reference point. In some cases, the involvement of nonriparians may be required. ${ }^{93}$ Second, legal regimes should emphasize the common interests of all relevant actors in the protection and preservation of the resource, rather than their competing sovereign interests. Third, in view of states' reluctance to subject sovereignty over resources to international interests, regimes should not aim at the "internationalization" of the resource itself. The notion of "common concern," which first emerged in the context of global environmental problems, can offer a conceptual framework here as well. Rights and obligations would exist only to the extent of the common concern and not challenge the sovereignty of states over their resources per se. By minimizing threats to sovereign control, a common concern framework might also facilitate the involvement of nonriparians in a freshwater regime and thus allow ecosystem management beyond the drainage basin. ${ }^{94}$ Fourth, while it is important to develop the geographical reach of legal regimes according to ecosystem criteria, evolution of their substantive content is equally important. The development of concrete norms for ecologically sound conduct must be promoted. It

\footnotetext{
${ }^{88}$ See text at notes $85-87$ supra.

${ }^{89}$ For example, the 1977 Ganges Agreement, supra note 67, focused strictly on apportionment of water quantities and fell into desuetude after 1985. See M. Asafuddowlah, Sharing of Transboundary Rivers: The Ganges Tragedy, in The Peaceful Management of Transboundary Resources 209 (G. H. Blake et al. eds., 1995). Benvenisti, supra note 35 , at 399 , suggests that water treaties have tended to be seen as discrete, rather than iterative, transactions, with emphasis placed on specific allocation rules. Applying insights from game theory, he finds that cooperation in the utilization of water resources must be structured as a long-term effort.

${ }^{90}$ See text at and notes 120-22 infra.

${ }^{91}$ Brunnée \& Toope, supra note 1 , at 55.

${ }^{92}$ Unless otherwise indicated, these conclusions can be found in id. at 75-76.

${ }^{93} I d$. at $72-73$.

${ }^{94} I d$. at $73-75$.
} 
can be guided by such emerging principles as sustainable development, intergenerational equity and the precautionary principle. ${ }^{95}$ Fifth, emerging regimes must consider the future and provide sufficient flexibility to accommodate new concerns and interests as they emerge. Yet, at the stage of regime development when legal norms emerge, these norms must be concrete enough to avoid conflict, which would occur if states pursued. incompatible activities on the basis of ambiguous standards. Sixth, substantive principles are important not only in shaping ecologically sound conduct; they also help regimes to form at a procedural level because they can inject a cooperative perspective. By identifying common goals, principles may promote the reshaping of previously competing interests through the processes and procedures provided by the regime. International lawyers have an important role to play in promoting such principles. ${ }^{96}$

One finds a striking overlap between our conclusions regarding the need for international ecosystem law and the insights of regime theory highlighted above. The requirements of international ecosystem law respond to many of the central themes of regime theory. For example, ecosystem-oriented principles on the scope and content of regimes can play a significant role in shaping arguments and expectations in a given context. They also determine who can and should participate in a regime based on value-laden criteria such as equity, fairness, transparency and justice, which enhance the credibility and legitimacy of the regime. Further, the application of regime theory to the freshwater context would facilitate evolution toward international ecosystem law. One could even posit that this evolution can only be achieved through a regime-oriented approach. Our understanding of effective regime formation as a fluid process, proceeding along a continuum and crystallizing binding norms in a dynamic context, resonates with international ecosystem law's emphasis on future-oriented, flexible and adaptable frameworks that nonetheless allow for the elaboration of specific norms on individual issues. Similarly, regime theory highlights the importance of overlapping cycles of cooperation and competition; international ecosystem law argues for a conceptual emphasis on cooperation in the common environmental interest, while acknowledging the reality of competing sovereign interests and differing priorities.

Ecosystem orientation of freshwater regimes, to be effective, must occur at two levels. On the one hand, freshwater regimes must be ecosystem-oriented in a substantive sense, requiring such principles as the drainage basin, common concern, sustainable development, intergenerational equity and the precautionary principle. ${ }^{97}$ On the other hand, freshwater regimes must be ecosystem-oriented in a procedural sense. They must rest on a framework - in terms of "process," perhaps ultimately leading to the elaboration of procedural rights and obligations and institutional mechanisms - that promotes the identification of common interests, the involvement of all relevant players and cooperation where ecologically essential, yet is sufficiently flexible to adapt to changing circumstances, allowing for evolution of the regime. ${ }^{98}$ Regime theory lends support to the argument that such a procedural framework is a necessary

\footnotetext{
${ }^{95} \mathrm{Id}$. at $65-70$.

${ }^{96}$ We have already suggested that international lawyers may actually form epistemic communities in certain issue-areas. This idea is in no way radical. For generations, it has been accepted that the writings of the "most highly qualified publicists" are at least a subsidiary source of international law. See INTERNATIONAL COURT OF Justice, STATUTE Art. 38(1) (d). We would argue that the rhetoric of "sources" in international law has been a limiting factor on its progressive development. However, the theory of epistemic communities confirms the role of international lawyers in the formulation of principles that, when promoted through various regimes, may ultimately harden into binding norms of international law.

${ }^{97}$ See text at note 12 supra.

${ }^{98}$ We will suggest that the framework-protocol model is particularly suited to providing such procedural ecosystem orientation within binding regimes, while also facilitating the framing of the regime according to substantive ecosystem principles. See text at and notes 190-96 infra.
} 
precondition to the realization of substantive ecosystem orientation and the continuing evolution of substantive norms.

Procedural frameworks typically arise within contextual regimes where states have already begun to identify shared concerns. Over the last fifteen years, the practice of international environmental law has developed a variety of models and strategies that might be employed in the freshwater context. Cooperation, and information gathering and exchange, are frequently woven together with formal institutional structures designed to promote the effectiveness and dynamic development of a treaty regime. These structures have emerged as crucial components of international environmental regimes. ${ }^{99}$ They have taken on tasks such as the collection of data and information, the receipt and publication of reports on the parties' implementation measures, and the facilitation of independent monitoring and scientific exchange. ${ }^{100}$ At the same time, the focus of regime building at this institutional level is not on the creation of bodies with original jurisdiction that could be perceived as challenging the sovereignty of participating states. These new institutions are very different from the multifarious mechanisms proposed by international lawyers in the 1960s and 1970s to "regulate" state behavior. ${ }^{101}$ What used to be perceived as institutional weakness has now emerged as a strength: the very fact that there is no effort to usurp jurisdiction ultimately allows the movement from purely state-centered approaches - with the regime prescribing little more than that states cooperate, offer certain information, take certain steps- to at least a tentative centralization of certain functions.

From the ecosystem perspective, the experience of international environmental law is significant in several respects. To the extent that institutional structures take on the collection and evaluation of data, the emphasis will shift from state interests to common ecological interests, from short-term to longer-term assessments. This effect is enhanced by the reliance on epistemic communities, which can depoliticize the identification of problems and priorities and thus make crucial contributions to the substantive evolution of the regime. ${ }^{102}$ When emerging institutional frameworks are informal and cooperative rather than jurisdictional in orientation, they also offer opportunities for broader and more diverse involvement by nonstate actors, which in other circumstances would be perceived as threatening to state sovereignty. Precisely because these institutional structures lack independent powers and operate through consensus, they have been able to promote continuous dialogue and a gradual merging of positions among parties. Moreover, ecosystem interests are better addressed when regimes are flexible enough to provide for the involvement of states other than those most obviously affected by the regime. ${ }^{103}$ In the end, all of these forces work together to move the regime along the continuum from coordination to solidification into normative frameworks of law. Finally, and perhaps most important, with the evolution from contextual regimes to legal regimes, formal institutions are commonly created that serve as fora for the review of

\footnotetext{
${ }^{99}$ See Katharina Kummer, Providing Incentives to Comply with Multilateral Environmental Agreements: An Alternative to Sanctions?, 3 EUR. ENVTL. L. REV. 256, 257 (1994).

${ }^{100}$ See Alan E. Boyle, Saving the World? Implementation and Enforcement of International Environmental Law Through International Institutions, 3 J. ENVTL. L. 229, 231 (1991).

${ }^{101}$ See, e.g., Joseph S. Clark \& Harry K. Schwartz, World Peace Through Law: The Lawyer's Job, 56 A.B.A. J. 953 (1970); Ved P. Nanda, Emerging Trends in the Use of International Water Resources, 6 DENV. J. INT'L L. \& POL'Y 239 (1976); A. O. Adede, Law of the Sea-Developing Countries' Contribution to the Development of the Institutional Arrangements for the International Sea-Bed Authority, 4 BROOKLYN J. INT'L L. 1 (1977); and Ivan A. Vlasic, Disarmament Decade, Outer Space and International Law, 26 MCGILL L.J. 135 (1981).

${ }^{102}$ This effect was illustrated by the recent experience of the Intergovernmental Panel on Climate Change (IPCC). See Oran R. Young, International Governance: Protecting the Environment in a Stateless SOCIETY 39-42 (1994); Daniel B. Bodansky, The Emerging Climate Change Regime, 20 ANN. REv. ENERGY \& ENV'T 425, 448 (1995).

${ }^{103}$ See text at notes 93-94 supra.
} 
implementation (or as some commentators prefer, "compliance") and the identification and negotiation of additional treaty obligations. ${ }^{104}$

The role of institutional structures also highlights the importance of implementation, dispute avoidance and dispute settlement, once a contextual regime has begun to solidify into a normative regime. It may therefore be helpful to trace some implications of regime theory and international ecosystem law for the definition and characterization of disputes in the international environmental context.

\section{Promoting Environmental Security: Implementation, Dispute Avoidance and Dispute Settlement}

The relationships among implementation, dispute avoidance and dispute settlement are complex and often interdependent. In recent analysis, "compliance" has emerged as alternative terminology for what would previously have been treated as state responsibility for breaches of international law. This trend encompasses efforts to define obligations with some precision (substantive approaches) and to create institutional structures that define breach even in the absence of black-letter rules (procedural approaches). ${ }^{105}$ Because the rhetoric of "breach" and the attendant state responsibility have proven unsuited to the enforcement of international environmental law, treaty institutions have elaborated less adversarial implementation and compliance mechanisms. ${ }^{106}$ In an attempt to encourage the progressive implementation of norms, negotiators and drafters of international environmental agreements have sought to discourage conflict by moving away from the terminology of "disputes." We would go further and avoid even the terminology of "compliance," for it still tends to promote the crystallization of issues as "disputes." The notion of "implementation" is broad enough to encompass the progressive development of norms and, when necessary, issues of adherence to established norms. ${ }^{107}$

In the Montreal Protocol on Substances That Deplete the Ozone Layer, the parties agreed to develop a specific noncompliance mechanism, ${ }^{108}$ independent of the formal dispute settlement procedure envisaged by the 1985 Vienna Convention for the Protection of the Ozone Layer. ${ }^{109}$ The Ad Hoc Working Group of Legal Experts on Non-

\footnotetext{
${ }^{104}$ See Boyle, supra note 100, at 231. See generally Abram Chayes \& Antonia H. Chayes, Adjustment and Compliance Processes in Intermational Regulatory Regimes, in Preserving the Global EnVIronment 280 (Jessica T. Mathews ed., 1991).

${ }^{105}$ Relatively ineffective attempts to help define disputes by creating precision in substantive obligations are apparent in the Convention on the Prevention of Marine Pollution by Dumping of Wastes and Other Matter, Dec. 29, 1972, 26 UST 2403, 1046 UNTS 120; the Rhine Chemical Convention, supra note 68; and the Rhine Chlorides Convention, supra note 68 . Procedural attempts to define disputes with greater precision can be found in most international environmental agreements. Even where the terminology of dispute is avoided in preference for that of noncompliance, the goal may be to establish a point of crystallization for the failure to comply with obligations. See text at and notes 108-14 concerning the noncompliance mechanism under the Montreal Protocol on Substances That Deplete the Ozone Layer.

${ }^{106}$ See Martti Koskenniemi, Breach of Treaty or Non-Compliance? Reflections on the Enforcement of the Montreal Protocol, 3 Y.B. INT'L ENVTL. L. 123, 125-28 (1992). Boyle, supra note 100, at 233, suggests that such mechanisms allow "the problems of treaty compliance and interpretation to be addressed from an administrative and political perspective, rather than from a judicial or adversarial one." CHAYEs \& CHAYEs, supra note 16, at 109, also argue for a cooperative, rather than an adversarial, approach. See also Kummer, supra note 99, at 257.

${ }^{107}$ In their useful study on compliance with international environmental accords, Jacobson and Weiss, supra note 54, at 123-25, distinguish "implementation" and "compliance" in a manner that does not wholly accord with our approach. For them, implementation "refers to measures that states take to make international accords effective in their domestic law." On the other hand, compliance goes beyond implementation, and refers to both implementation of specific treaty obligations and adherence to the "spirit of the treaty."

${ }^{108}$ Montreal Protocol on Substances That Deplete the Ozone Layer, Sept. 16, 1987, reprinted in 26 ILM 1550 (1987). Article 8 required the parties, "at their first meeting, [to] consider and approve procedures and institutional mechanisms for determining non-compliance with the provisions of the Protocol and for the treatment of the Parties found to be in non-compliance."

${ }^{109}$ See Convention for the Protection of the Ozone Layer, Mar. 22, 1985, Art. 11, TLAS No. 11,097, reprinted in 26 ILM 1529 (1987) [hereinafter Vienna Convention]; Annex II to the Convention sets out detailed information exchange provisions.
} 
Compliance was created and charged, inter alia, with the identification of "advisory and conciliatory measures to encourage full compliance." 110 The procedure aims at encouraging and facilitating compliance, rather than simply defining noncompliance for the purpose of identifying a breach of obligations. In this spirit, the body created to administer the noncompliance procedure is known as the Implementation Committee. ${ }^{11}$ In its practice to date, the committee has "operated in a cooperative, non-judicial and non-confrontational atmosphere." 112 This approach, hailed as "unprecedented in international environmental law," ${ }^{113}$ has apparently been successful. So far, the committee's discussions of actual or potential noncompliance by various parties to the Montreal Protocol have been sufficient to induce most of them to comply or to reach agreements with the committee on future compliance. ${ }^{114}$

A similar "two-track" approach, in this case providing for a dispute avoidance channel distinct from the formal dispute settlement procedure, was established by the 1991 Convention on Environmental Impact Assessment in a Transboundary Context of the Economic Commission for Europe (ECE). ${ }^{115}$ Given its preventive goals, the Espoo Convention's equivalent of the "noncompliance procedure" is focused not so much on whether a party has failed to comply, but on whether a situation exists that requires compliance. Thus, when the "Parties cannot agree whether there is likely to be a signifi-

${ }^{110}$ Decision III/2 of the 1991 Meeting of the Parties, discussed in THE EFFEctiveness OF InTERNATIONAL Environmental Agreements 141 (Peter H. Sand ed., 1992). The final version of the procedure was adopted at the fourth Meeting of the Parties, in 1992. See Doc. UNEP/OzL.Pro.4/15 (1992), reprinted in 3 Y.B. INT'L ENVTL. L. 819 (1992) [hereinafter Fourth Meeting]. It allows any party to register a "reservation" with respect to the implementation of the Protocol's obligations by another party. An "Implementation Committee," consisting of 10 members elected by the Meeting of the Parties "based on equitable geographical distribution," will review the reservation, the reply of the party concerned and any other relevant information to secure an "amicable solution." The results of the review will be communicated to the Meeting of the Parties, which is to determine any steps to bring about full compliance, including measures to assist parties' compliance. To assist these two bodies in their respective functions, an "Indicative List" identifying "possible situations of non-compliance" and an "Indicative List of Measures" to encourage full compliance were also developed. See Report of the Third Meeting of the Ad Hoc Working Group of Legal Experts on Non-Compliance with the Montreal Protocol, Doc. UNEP/OzL.Pro/WG.3/3/3, Annex II, point I (1992). The Implementation Committee may also scrutinize national reports to determine the implementation efforts of the parties, which enhances the effect of the reporting requirements and encourages participation in the reporting system, as the committee publishes a list of states that have failed to submit their reports. See Fourth Meeting, supra, para. 7(b).

${ }^{111}$ For an overview, see Patrick Széll, Implementation Control: Non-Compliance Procedure and Dispute Settlement in the Ozone Regime, in The Ozone Treaties and THEIR Influence on THE Building OF InTERnational EnVIRONMENTAL Regimes 43, 46-47 (Oesterreichische aussenpolitische Dokumentation, Special Issue, Winfried Lang ed., 1996).

${ }^{112}$ Report of the Seventh Meeting of the Parties to the Montreal Protocol on Substances That Deplete the Ozone Layer, Doc. UNEP/OzL.Pro.7/12, para. 39 (1995) (Report of the President of the Implementation Committee) 〈http://acd.ucar.edu/gpdf/ozone/mp/mop7-report.html\#sV〉 [hereinafter Seventh Meeting].

${ }^{113}$ Koskenniemi, supra note 106, at 133. But see David G. Victor, The Montreal Protocol's Non-Compliance Procedure: Lessons for Making Other International Environmental Regimes More Effective, in THE OzONE TREATIES AND THEIR INFLUENCE ON THE BUILDING OF INTERNATIONAL ENVIRONMENTAL REGIMES, supra note 111, at 58, passim.

${ }^{114}$ At the fifth Meeting of the Parties in 1993, the Implementation Committee met with parties not in compliance. These meetings occurred "at the margins of the full conference" and resulted in most parties" confirming "their readiness to comply." See Winfried Lang, Air and Atmosphere: The Year in Review, 4 Y.B. INT'L ENVTL. L. 141 (1993) (noting that this outcome may have been due to the " 'amicable' approach adopted by the Committee, which spares non-compliers full exposure . . . provided they promise their performance"). In 1994 the Implementation Committee met prior to the sixth Meeting of the Parties to discuss the noncompliance of Algeria, Antigua and Barbuda, the Central African Republic, Iran, Lebanon, Swaziland, and the Syrian Arab Republic. See Winfried Lang, Air and Atmosphere: The Year in Review, 5 Y.B. INT'L ENVTL. L. 161 (1994) (stating that some of these countries submitted last-minute reports to avoid further action). Finally, in 1995 the committee determined that Belarus, Bulgaria, the Russian Federation, Ukraine and Poland were facing possible noncompliance in 1996. Discussions in the committee resulted in decisions by the parties with respect to each of these countries. Four of them entered into agreements providing for actions to be taken to achieve compliance and for assistance to be granted to them in this vein. Only Russia objected to the decision on its noncompliance. See Seventh Meeting, supra note 112, paras. 39-44, 94, 123-34.

${ }^{115}$ See Convention on Environmental Impact Assessment in a Transboundary Context, Feb. 25, 1991, reprinted in 30 ILM 800 (1991) [hereinafter Espoo Convention]. 
cant adverse transboundary impact, any such Party may submit that question to an inquiry commission . . . to advise on the likelihood of significant adverse transboundary impact, unless they agree on another method of settling this question." 116

As can be seen, the terminology of compliance or implementation is closely allied with the concept of dispute avoidance. For international lawyers, dispute avoidance has tended to be defined in terms of concrete mechanisms of information sharing, exchange of scientific data, prior notification and fact-finding, such as those envisaged by the Vienna Convention and the Espoo Convention. ${ }^{117}$ But avoidance techniques are also relevant to disputes once they have crystallized. For example, fact-finding and information sharing may go some way toward the confidence building that prevents disputes from arising, but they may also be essential to the settlement of a dispute that has already arisen. Some treaty regimes attempt to avoid the crystallization of disputes entirely through a terminological sleight of hand: "issues" are identified and addressed before concrete "disputes" are named. As in the Espoo Convention, ${ }^{118}$ these "issues" may not even be identified in terms of compliance, despite relating to the normative obligations imposed upon parties to a treaty regime. ${ }^{119}$

While acknowledging inevitable overlap, we believe that shared freshwater resources demand regimes in which implementation is encouraged through positive measures, in preference to sanctions, and dispute avoidance is given higher priority than third-party dispute settlement. The ecosystem approach argued for above, when matched with the adoption of a broader view of environmental security that emphasizes ecosystem integrity, points to further relevant considerations. First, the number of actors implicated in the elaboration of a freshwater regime will often be large. Second, the range of factors relevant to any decision concerning shared freshwater resources is potentially enormous. To adopt Lon Fuller's terminology, conflicts of interest (or perceived interest) in this context are highly polycentric and perhaps not amenable to more formal mechanisms of dispute settlement. ${ }^{120}$ Finally, dispute settlement procedures (as distinct from dispute avoidance processes) are often, though not necessarily, linked to confrontational forms of advocacy and to adversarial processes of articulation. Such processes tend to produce "cases," which are rooted in assertions of exclusive state control over territory and perceived (and misperceived) national interests.

In such a conflictual context, the interests of individuals and groups, future generations and the ecosystem per se cannot easily obtain a hearing and will not necessarily be given pride of place in any dispute avoidance processes entirely controlled by states. The hegemony of state interests is more easily confronted in informal processes, which are not directed toward meting out penalties for noncompliance, and whose results are not immediately viewed as "binding." As is apparent from the dispute settlement regimes

\footnotetext{
${ }^{116} I d$., Art. 3(7). Appendix IV to the Convention sets out the "inquiry procedure," which begins with the establishment of a three-member inquiry commission: Each party designates a scientific or technical expert and a third expert is chosen by common agreement to be president of the commission (para. 2). If a party fails to participate in this step, the Executive Secretary of the ECE is empowered to appoint either the commission member or the president, as the case may be (paras. 3, 4). Each party must assist the commission by providing necessary information and facilities (para. 7). However, if one party refuses to appear before the commission or present its case, the commission may nonetheless complete its work (para. 9). Other parties may intervene in the proceedings if they have an interest in the issue and may be affected by the outcome (para. 11). At the end of the process, the commission submits a final opinion to the parties and the secretariat (paras. 13, 14).

${ }^{117}$ See Viznna Convention, supra note 109, Arts. 2-6; and Espoo Convention, supra note 115, Arts. 2, 3, 5 and Apps. I, III. See also Kamen Sachariev, Promoting Compliance with International Environmental Legal Standards: Reflections on Monitoring and Reporting Mechanisms, 2 Y.B. INT'L ENVTL. L. 31 (1991).

${ }_{118}$ See Espoo Convention, supra note 115, Art. 3(7).

${ }^{119}$ See, e.g., Protocol on Environmental Protection to the Antarctic Treaty, Oct. 4, 1991, Art. 13(4), reprinted in 30 ILM 1455 (1991).

${ }^{120}$ Lon L. Fuller, The Forms and Limits of Adjudication, 92 HARV. L. REV. 353 (1978).
} 
that states have negotiated to date, they are most reluctant to cede any control when a decision may prove to be legally binding. It is noteworthy that despite the numerous dispute settlement provisions included in international environmental treaties, these mechanisms are not widely employed. Dispute avoidance schemes linked to river commissions, such as consultation mechanisms and prior notification rules, have proven useful, but most third-party dispute settlement processes remain unused. ${ }^{121}$

The reluctance to employ formal mechanisms of dispute resolution should come as no surprise to anyone acquainted with regime theory. The effectiveness of formal mechanisms is likely to depend upon the degree to which they are embedded in contextual regimes where shared perspectives have evolved-and political and legal legitimacy has been recognized and accepted. Often, when international lawyers follow their professional instincts, premature attempts are made to elaborate "binding" mechanisms of normative definition and control. The mechanisms are created in a vacuum, where no actual practice of dispute resolution has been evolving within a preexisting contextual regime. ${ }^{122}$ Now it may be that over time a contextual regime will harden in such a way that binding mechanisms of dispute resolution become useful. But such mechanisms are best defined at that point, so that they are truly appropriate to the level of cooperation present within the regime. As we have already argued, international lawyers have a role to play in encouraging that process by articulating principles that come to shape the attitudes of states regarding the given issue-area. Although the role of "publicist" may be less congenial to some lawyers than that of institutional designer, we suggest that attempts to create notionally binding mechanisms of dispute resolution at a premature phase in regime formation should be resisted.

It follows from the preceding discussion that dispute resolution mechanisms negotiated for regimes that are just emerging from the coordinated practice of states are more likely to be successful if relatively informal. Not only are negotiation, conciliation and mediation more readily invoked by states than third-party dispute resolution, but they tend to produce results with some real impact on state behavior. Further, and this suggestion is perhaps more challenging, if the road of dispute avoidance is preferable to that of dispute settlement, the attempt to define noncompliance and to acknowledge the crystallization of a dispute may be ill-conceived, particularly in the early days of regime evolution. The various dispute avoidance techniques are predicated on continuing dialogue. Confidence-building measures are likely to collapse if the parties perceive themselves as in the midst of a dispute.

\section{FreshwATER Regimes FOR THE FUtURE}

We now draw together our suggestions for structuring future freshwater regimes and reorienting existing regimes. As we have tried to show, effective regimes must be premised on substantive and procedural ecosystem orientation. We can draw upon various existing freshwater regimes that point to gradual substantive evolution in this direction and are consonant with the version of regime theory we have posited. With respect to procedural ecosystem orientation, we argue that promising models can be found both

${ }^{121}$ For examples of such provisions, see, e.g., Antarctic Treaty, Dec. 1, 1959, Art. XI(1) \& (2), 12 UST 794, 402 UNTS 71; Convention for the Prevention of Marine Pollution from Land-Based Sources, Feb. 21, 1974, Arts. 16, 21, and Annex B, reprinted in 13 ILM 352 (1974); and the Basel Convention on the Control of Transboundary Movements of Hazardous Wastes and Their Disposal, Mar. 22, 1989, Art. 20 \& Ann. VI, reprinted in 28 ILM 657 (1989). The summary report to THE EFFECTIVENESS OF INTERNATIONAL ENVIRONMENTAL AGREEMENTS, supra note 110, at 14, observes: "Even though many of the global and regional agreements surveyed contain provisions and detailed annexes for dispute resolution . . . there are no known cases in which any of these provisions were invoked or used."

${ }^{122}$ See Martti Koskenniemi, Peaceful Settlement of Environmental Disputes, 61 NoRDIC J. INT'L L. 73,82 (1991). 
in the freshwater context and in other recent international environmental protection regimes.

\section{The Emergence of Substantive Ecosystem Orientation}

Recently, freshwater regimes have evolved that take a comprehensive approach to the shared resource and incorporate some of the ecosystem principles discussed in this paper. Interestingly, there is also a move away from exclusive emphasis on normative approaches aimed at legally binding arrangements, as well as increasing evidence of new strategies rooted in what we have called contextual regimes. For example, the formulation in Agenda 21 of nonbinding principles to guide freshwater management is an early and broadly focused contextual regime. ${ }^{123}$ The conceptual steps taken in chapter 18 of Agenda 21, and the explicit formulation of guiding principles, occurred before regimes had evolved in specific settings. Promoters of freshwater regimes can now look to Agenda 21 for principles to guide normative evolution. For this reason, it is particularly significant that chapter 18 stresses the importance of "holistic management of freshwater as a finite and vulnerable resource," 124 and states that, "[i] in developing and using water resources, priority has to be given to the satisfaction of basic needs and the safeguarding of ecosystems." ${ }^{125}$ Further, it calls for "integrated water resources management, including the integration of land- and water-related aspects, . . . at the level of the catchment basin or sub-basin." 126

At the same time, chapter 18 is weak in extrapolating possible new institutional responses from these principles. It merely calls for cooperation by the riparians of transboundary water resources, ${ }^{127}$ suggesting that harmonization of national water resources strategies and action programs may be required. ${ }^{128}$ Chapter 18 outlines an approach to cooperation and cooperative mechanisms that operates at the lowest appropriate national, regional or global level, apparently on the basis of a principle of subsidiarity. ${ }^{129}$ Throughout, the chapter assumes the state level to be the appropriate one for regulatory and institutional responsibility, portraying international activities as voluntary cooperation and as "subject to the prior agreement of each riparian State concerned." 130 There is a certain contradiction within chapter 18. It urges that "[1] ong-term development of global freshwater requires holistic management of resources and a recognition of the interconnectedness of the elements related to freshwater and freshwater quality," 131 yet its prescriptions for coordination at the international level are timid at best. ${ }^{132}$ Despite this apparent contradiction, when considered from the perspective of regime formation

${ }^{123}$ See Agenda 21, Chapter 18-Protection of the Quality and Supply of Freshwater Resources: Application of Integrated Approaches to the Development, Management and Use of Water Resources, UN Doc. A/ CONF.151/26 (Vol. 2) (1992), reprinted in UN Sales No. E.93.I.11 (1993).

${ }_{124}^{12}$ Id., para. 18.6; see also paras. $18.35,18.36$

${ }^{125}$ Id., para. 18.8 .

${ }^{126}$ Id., para. 18.9; see also para. 18.38 (a).

${ }^{127}$ Id., para. 18.4, states that "[ $\left.\mathrm{t}\right]$ ransboundary water resources and their use are of great importance to riparian States. In this connection, cooperation among those States may be desirable in conformity with existing agreements and/or other relevant arrangements, taking into account the interests of all riparian States concerned."

${ }^{128}$ According to $i d$., para. 18.10, " [i] n the case of transboundary water resources, there is a need for riparian States to formulate water resources strategies, prepare water resources action programmes and consider, where appropriate, the harmonization of those strategies and action programmes."

${ }^{129}$ Id., paras. 18.12(o), 18.22. See also Ellen Hey, Sustainable Use of Shared Freshwater Resources: The Need for a Paradigmatic Shift in International Watercourses Law, in The Peaceful Management of Transboundary ReSOURCES, supra note 89, at 127, 133.

${ }_{130}$ Agenda 21, supra note 123, para. 18.27(a) (iv).

${ }^{131}$ Id., para. 18.35.

${ }^{132}$ See Hey, supra note 129 , at 136 . Chapter 18 portrays the international dimension to freshwater management as one of offering advice and suggestions for domestic activities, rather than as another layer of regulation and management. See, e.g., Agenda 21, supra note 123, paras. 18.39, 18.40. 
as discussed in this paper, Agenda 21 may be said to recognize the relevant dynamics and the futility of issuing institutional prescriptions before the underlying substantive principles have gained acceptance. As we have indicated, the value of Agenda 21 rests in its contribution to the crystallization of concepts that can be transplanted into and shape individual international regimes and agreements.

A similar interest in the crystallization of concepts underlies the International Law Commission's draft articles on the law of the non-navigational uses of international watercourses. ${ }^{133}$ In attempting to provide a blueprint for legally binding freshwater regimes, the draft articles were explicitly intended to produce normative consequences. However, through the articulation of principles, the ILC effort may also serve to foster a parallel contextual regime. By formulating legal and structural ground rules for freshwater agreements and emphasizing the need for binding treaties, the draft articles seem to follow in a formalistic "lawmaking" tradition. Yet they are not necessarily inconsistent with regime-oriented thinking, as they can make a valuable contribution to the shaping of norms, whether treaty based or customary, when consolidation into a legal regime occurs.

Unfortunately, from the perspective of international ecosystem law, the draft articles represent a missed opportunity. Clearly, the room of the ILC to maneuver was significantly constrained by both its mandate and the need to root its work in the principles and practice of international water law accepted by most states. ${ }^{134}$ It is nonetheless regrettable that the Commission could not emphasize the aspect of its mandate related to the progressive development of international law and promote the urgently needed synthesis of international water law and international environmental law. ${ }^{135}$ Despite the inclusion of principles aimed at the protection both of the ecosystems of international watercourses and of the marine environment, ${ }^{136}$ the draft articles remain grounded in the traditional paradigm of international environmental protection as "transboundary" and premised on the balancing of competing sovereign interests and the use of resources. ${ }^{137}$ The articles do not sufficiently reflect the gradual progression toward an ecosystem orientation in international environmental law. Although argued to be implicit in some of the proposed provisions, ${ }^{138}$ the increasingly accepted principles of sustainable development, intergenerational equity and precaution are not incorporated into the text. ${ }^{139}$ Similarly, the Commission was unable to define the geographical reference point of its articles, the "international watercourse," in terms of the drainage basin but maintained a narrower definition. ${ }^{140}$ Finally, although Article 20 introduces the ecosystem

${ }^{133}$ ILC 1994, supra note 74.

${ }^{134}$ See Brunnée \& Toope, supra note 1 , at 58.

135 See GA Res. 2669 (XXV), UN GAOR, 25th Sess., Supp. No. 28, at 127, UN Doc. A/8028 (1970) (calling on the Commission to "take up the study of the law of the non-navigational uses of international watercourses with a view to its progressive development and codification" (emphasis added)).

${ }^{136}$ ILC 1994, supra note 74, Arts. 20, 23. See also Brunnée \& Toope, supra note 1, at 64-65.

${ }^{137}$ The prohibition of significant transboundary harm and the requirement of equitable utilization remain the overarching concepts. See ILC 1994, supra note 74, Arts. 5, 7, 21. See also Brunnée \& Toope, supra note 1, at $61-64$.

${ }^{138}$ The commentary suggests at various points that notions such as precaution and sustainable development are implied by the draft articles. See ILC 1994, supra note 74, at 219, 287.

${ }^{139}$ See Brunnée \& Toope, supra note 1, at 65-70. Note, however, that the concept of sustainable development is mentioned in Article 24, dealing with the possible tasks of a joint management mechanism. Note also that the ILC appears to view the precautionary principle as inherent in Article 21(2), pursuant to which pollution that "may cause" significant harm is to be prevented, controlled or reduced. See ILC 1994, supra note 74, at $289,292$.

${ }^{140}$ According to ILC 1994, supra note 74, Art. 2, an international watercourse is "a system of surface and underground waters constituting by virtue of their physical relationship a unitary whole and normally flowing into a common terminus." See Brunnée \& Toope, supra note 1, at 60. But see text at note 134 supra (pointing to the constraints faced by the ILC by virtue of the mandate it received from the UN General Assembly to study "the law of the non-navigational uses of international watercourses" (emphasis added)). 
concept by calling on states to "protect and preserve the ecosystems of international watercourses," the Commission formulated this obligation without providing for matching rights of other states. ${ }^{141}$ Rather, the draft articles retain the traditional approach pursuant to which environmental harm triggers rights only where transboundary effects are felt. As a result, those looking for guidance in formulating the substantive principles on which to build a freshwater agreement will have to look beyond the draft articles for the key elements of an ecosystem-oriented approach. ${ }^{142}$

Another regime that functions in a contextual fashion, even though its explicit aim is the immediate promotion of binding legal norms, is the ECE Convention on the Protection and Uses of Transboundary Watercourses and International Lakes (Helsinki Convention). ${ }^{143}$ Like Agenda 21 and the ILC draft articles, the Helsinki Convention is not intended to govern the relations of states in a specific river basin. The Convention, however, arguably aided by its regional rather than its global context, adopts a more assertive approach than the other two documents. It requires parties to subscribe to certain basic principles, which will guide and serve as minimum standards for their practice or as cornerstones for individual transboundary water agreements. ${ }^{144}$ Through a broad definition of "transboundary impact," one of its central concerns, the Convention acknowledges the interaction between water and other components of the ecosystem. ${ }^{145}$ Conservation and restoration of ecosystems are among the goals to be achieved by the parties and, in their efforts to prevent, control or reduce transboundary impacts, they are to promote "[s] ustainable water-resources management, including . . . the ecosystems approach." ${ }^{146}$ Further, among the principles to guide the parties' practice are the precautionary principle and the notion of intergenerational equity. ${ }^{147}$ Given that all parties to the Helsinki Convention, as well as those entering subsequent riparian agreements, must now take these prescriptions as a base in their practice, the Convention's contributions to substantive ecosystem orientation are significant.

Its influence is already noticeable at the level of individual basin agreements and thus, from the perspective of regime formation, at the stage of consolidation into binding legal form. For example, in their Preamble and Article 2, the 1994 Agreements on the Protection of the Rivers Scheldt and Meuse explicitly refer to the Helsinki Convention. ${ }^{148}$ The scope of the Agreements is defined by three concepts: the riverbed, the river basin and the drainage area; ${ }^{149}$ participation by nonriparians with territory in the drainage

\footnotetext{
${ }^{141}$ For a discussion, see Brunnée \& Toope, supra note 1, at 64-65.

${ }^{142}$ Unfortunately, the same may be true in the context of procedural ecosystem orientation. See infra text at and notes $171-75$.

${ }^{143}$ Convention on the Protection and Use of Transboundary Watercourses and International Lakes, Mar. 17, 1992, reprinted in 31 ILM 1312 (1992) [hereinafter Helsinki Convention].

${ }^{144} I d$., Art. 2, paras. 1, 2, 5, 6, 8, and Arts. 3, 9.

${ }^{145}$ In id., Art. 1, para. 2, "transboundary impact" is defined as
}

any significant adverse effect on the environment resulting from a change in the conditions of transboundary waters caused by a human activity, the physical origin of which is situated wholly or in part within an area under the jurisdiction of a Party, within an area under the jurisdiction of another Party. Such effects on the environment include effects on human health and safety, flora, fauna, soil, air, water, climate, landscape and historical monuments or other physical structures or the interaction among these factors; they also include effects on the cultural heritage or socio-economic conditions resulting from alterations to those factors.

${ }^{146} I d$., Art. 2, para. 2(d), and Art. 3, para. 1(i). In Annexes II and III, the Convention also provides guidelines for the development of "best environmental practices" and "water-quality objectives and criteria," respectively.

${ }_{147} I d$., Art. 2, para. 5(a) \& (c).

${ }^{148}$ Agreements on the Protection of the Rivers Scheldt and Meuse, Apr. 26, 1994, reprinted in 34 ILM 851 (1995) [hereinafter Scheldt and Meuse Agreements]. For an overview, see A. Gosseries, The 1994 Agreements Concerning the Protection of the Scheldt and Meuse Rivers, 4 Eur. ENVTL. L. REv. 9 (1995).

${ }^{149}$ See Scheldt and Meuse Agreements, supra note 148, Arts. 1. 
area is envisaged. ${ }^{150}$ The principles guiding the parties' cooperation echo those in the Helsinki Convention and include the precautionary principle, the notion of sustainable development and an undertaking to protect the quality of aquatic ecosystems. ${ }^{151}$

Aside from the influence of contextual freshwater regimes, numerous examples of substantive ecosystem orientation can be found in freshwater agreements negotiated over the last twenty years. While the older ones only partially reflect ecosystem principles, a more comprehensive reorientation is noticeable in the most recent agreements. Of all the ecosystem principles relevant to freshwater, the notion of the drainage basin has the longest history. As early as the 1960s, some African agreements incorporated the concept. ${ }^{152}$ Since the $1970 \mathrm{~s}$, it has become the basis of freshwater agreements in various parts of the world, ${ }^{153}$ and such treaties have begun to give expression to the ecosystem dimension of freshwater management and the interaction of different environmental media. ${ }^{154}$ Finally, since the 1980 s, treaties have been negotiated that incorporate the principles of sustainable development, intergenerational equity and precaution. ${ }^{155}$ While the 1987 Agreement on the Action Plan for the Environmentally

${ }^{150} I d$., Arts. 7 (observers) \& 10, para. 1 (subsequent accession).

${ }^{151} I d$., Arts. 3, paras. 2(a), 5, 6 .

${ }^{152}$ See Act Regarding Navigation and Economic Co-operation between States of the Niger Basin, Oct. 26, 1963, reprinted in Rüster \& Simma, supra note 66, at 5629 [hereinafter Niger Basin Agreement]; Convention and Statute Relating to the Development of the Chad Basin, May 22, 1964, reprinted in id. at 5633 [hereinafter Chad Basin Convention].

${ }^{153}$ See, e.g., Treaty on the River Plate [Plata] Basin, Apr. 23, 1969, reprinted in 8 ILM 905 (1969); Agreement on Great Lakes Water Quality, Apr. 15, 1972, Art. I(d), 1972 Can. TS No. 12, 23 UST 301 [hereinafter 1972 GLWQA]; Rhine Chemical Convention, supra note 60, Art. 1; Kagera River Agreement, Aug. 24, 1977, reprinted

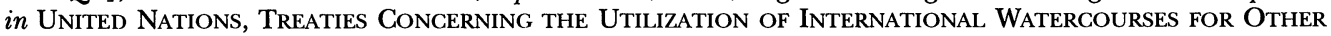
Purposes Than Navigation, Africa 32, UN Sales No. E/F.84.II.A.7 (1984); Treaty for Amazonian Cooperation, July 3, 1978, Art. II, reprinted in 17 ILM 1045 (1978); Agreement on the Action Plan for the Environmentally Sound Management of the Common Zambezi River System, May 28, 1987, reprinted in 27 ILM 1109 (1988) [hereinafter Zambezi Agreement]; Agreement Concerning Co-operation on Management of Water Resources of the Danube Basin, Dec. 1, 1987, 1990 O. J. (L 90) 20, reprinted in 2 BASIC DocUmENTS OF INTERNATIONAL Environmental Law, Doc. 54E (Harald Hohmann ed., 1992); Agreement on the Preparation of a Tripartite Environmental Management Programme for Lake Victoria, Nov. 30, 1993, attachment 1.2, reprinted in INTERNATIONAL ENVIRONMENTAL LAW-Multilateral AGREEMENTS 994 (W. E. Burhenne et al. eds., 1974) [hereinafter Lake Victoria Agreement]; Convention on Cooperation for the Protection and Sustainable Use of the Danube River Basin, June 29, 1994, reprinted in 19 Int'l Env't Rep. (BNA) 997 (Oct. 30, 1996); and Strategic Action Plan for the Danube River Basin 1995-2005 〈http://pan.cedar.univie.ac.at/data/danis/docs/sap1.html [hereinafter Danube Action Plan]; Scheldt and Meuse Agreements, supra note 148; and Agreement on Cooperation for the Sustainable Development of the Mekong River Basin, Apr. 5, 1995, reprinted in 34 ILM 864 (1995) [hereinafter Mekong Agreement].

${ }^{154}$ In 1964 the Chad Basin Convention, supra note 152, already committed its parties to consider impacts upon water or biological characteristics of fauna and flora in the Chad Basin (Art. 5). Developments since the 1970s include the Uruguay River Statute, Feb. 26, 1975, Arts. 35, 36, quoted in Stephen M. Schwebel, Third Report on the Law of the Non-Navigational Uses of International Watercourses, [1982] 2 Y.B. Int'l L. Comm'n 65, 96, UN Doc. A/CN.4/SER.A/1982/Add.1 (Part 1) (paying attention to the interaction between land and water, and the need to maintain ecological balance); Agreement on Great Lakes Water Quality, Nov. 22, 1978, Art. 1(g), 1978 Can. TS No. 20, 30 UST 1383, 1153 UNTS 187 (referring to the Great Lakes Basin ecosystem as interrelating "components of air, land, water and living organisms, including man") [hereinafter 1978 GLWQA]; see text at note 164 infra for the altered wording adopted in 1987; Zambezi Agreement, supra note 153, Annex I, para. 14 (recognizing the need to integrate other environmental concerns into water management); Declaration of San Francisco de Quito, Mar. 7, 1989, Preamble, reprinted in AMAZONIA AND SIBERIA: Legal Aspects of the Preservation of THE EnVIronment and Development in the LAST Open Spaces 334 (Michael Bothe et al. eds., 1993) (elaborating on the Treaty for Amazonian Cooperation, supra note 153, and recognizing the importance of Amazonian ecosystems); Lake Victoria Agreement, supra note 153, Complement 2; Scheldt and Meuse Agreements, supra note 148, Arts. 5(d) (recognizing the need to "improve the quality of the water and of the ecosystem generally"); Mekong Agreement, supra note 153, Preamble \& Art. 3 (recognizing the need to protect the ecological balance of the basin, related natural resources and the environment).

${ }^{155}$ See Zambezi Agreement, supra note 153, Preamble \& Annex I (referring repeatedly to the concept of sustainable development); see also Amazon Declaration, May 6, 1989, reprinted in 28 ILM 1303 (1989) (acknowledging the Amazon states' common interest, "within the framework of the Treaty for Amazonian Co-operation," in sustainable development (para. 1) and referring to the need for environmental protection and 
Sound Management of the Common Zambezi River System and the 1995 Agreement on Cooperation for the Sustainable Development of the Mekong River Basin stand out for their prominent use of some of these concepts, ${ }^{156}$ the most evolved manifestation of ecosystem-oriented freshwater management remains the Great Lakes Water Quality Agreement. ${ }^{157}$

Although the GLWQA does not make explicit reference to sustainable development, intergenerational equity or precaution, these principles are inherent in its futureoriented approach and detailed criteria for ecosystem management. ${ }^{158}$ In response to concerns over deteriorating water quality in the Great Lakes region, the 1972 GLWQA established a framework for the development of specific water quality objectives and programs. ${ }^{159}$ In 1978, while maintaining the 1972 Agreement's basic structure, ${ }^{160}$ the GLWQA was amended to make explicit the purpose of restoring the Great Lakes Basin ecosystem. ${ }^{161}$ Pursuant to this overarching purpose, the parties endorsed a "philosophy" of "zero discharge" of persistent toxic contaminants, ${ }^{162}$ arguably adopting a precautionary approach. ${ }^{163}$ A 1987 Protocol further amended the GLWQA, which now explicitly defines the Great Lakes ecosystem as "the interacting components of air, land, water and living organisms, including humans, within the drainage basin." 164 The idea of transboundary ecosystem management is also reinforced by six thematic amendments, providing for (1) specific reporting deadlines and clear roles for the

conservation for the benefit of present and future generations (para. 2)); Mekong Agreement, supra note 153, Preamble \& Art. 1 (emphasizing the need for sustainable development).

${ }^{156}$ Critical voices have suggested that the Mekong Agreement, despite its progressive terminology, ultimately permits projects such as large dams, which could destroy the basin's ecological balance. The most recent meeting (March 18-19, 1996) of the Joint Committee of the Mekong River Commission brought no agreement on issues such as pollution control and environmental protection. However, from April 17 to 20, 1996, the members participated in a workshop examining the experience with other basin development plans. See Differences Remain Among Four Nations over Curbing Pollution in Mekong River Delta, 19 Int'l Env't Rep. (BNA) 285 (Apr. 3, 1996).

${ }^{157}$ Ultimately anchored in the 1909 Boundary Waters Treaty, supra note 69, the GLWQA evolved through the following agreements: the 1972 GLWQA, supra note 153; the 1978 GLWQA, supra note 154; and the Protocol Amending the Agreement between the United States of America and Canada on Great Lakes Water Quality of 1978, Nov. 18, 1987, 1987 Can. TS No. 32, TIAS No. 11,551 [hereinafter 1987 Protocol].

${ }^{158}$ For detailed reviews, see, e.g., Daniel K. DeWitt, Great Words Needed for the Great Lakes: Reasons to Rewrite the Boundary Waters Treaty of 1909, 69 IND. L.J. 299 (1993); John Jackson, The Great Lakes: Exploring the Ecosystem, in Resource Politics-Freshwater and Regional Relations 23 (Caroline Thomas \& Darryl Howlett eds., 1994); Leonard B. Dworsky et al., The Great Lakes: Transboundary Issues for the Mid-90's, 26 U. ToL. L. REV. 347 (1995). For critical voices, see, e.g., Lynton K. Caldwell, Disharmony in the Great Lakes Basin: Institutional Jurisdictions Frustrate the Ecosystem Approach, AlternATIves, July 1994, at 26; William J. Christie, The Ecosystem Approach to Managing the Great Lakes: The New Ideas and Problems Associated with Implementing Them, 26 U. TOL. L. REV. 279 (1995).

${ }_{159}$ See Richard B. Bilder, Controlling Great Lakes Pollution: A Study in United States-Canadian Environmental Cooperation, 70 Mich. L. REv. 469, 499-500 (1972).

${ }^{160}$ Like its predecessor, the 1978 GLWQA, supra note 154, provides for "general objectives" (Art. III) and "specific objectives" (Art. IV), which are to be implemented through agreed-upon "standards" (Art. V) derived from "programs and other measures" dealing with various pollution sources (Art. VI). Detailed annexes develop these elements.

${ }^{161}$ Article II, id., reads in part:

The purpose of the Parties is to restore and maintain the chemical, physical, and biological integrity of the waters of the Great Lakes Basin Ecosystem. In order to achieve this purpose, the Parties agree to make a maximum effort to develop programs, practices and technology necessary for a better understanding of the Great Lakes Basin Ecosystem and to eliminate or reduce to the maximum extent practicable the discharge of pollutants into the Great Lakes System.

${ }^{162} I d$., Annex 12, para. 2(a) (ii). This approach, however, has not yet yielded the desired result of "zero discharge" in practice. See Paul Muldoon \& John Jackson, Keeping the Zero in Zero Discharge: Phasing out Persistent Toxic Substances in the Great Lakes Basin, AlternATIves, Sept. 1994, at 14.

${ }^{163}$ Another example of the implicit adoption of the precautionary approach is the lists of toxic or potentially toxic substances developed under the 1987 Protocol, supra note 157.

${ }^{164}$ Id., Art. II(a), amending 1978 GLWQA, supra note 154, Art. 1(g) (emphasis added). 
governments involved, as well as the International Joint Commission; ${ }^{165}$ (2) three priority lists of toxic or potentially toxic substances; ${ }^{166}(3)$ commitments to biannual consultations to consider the need for new objectives;" ${ }^{167}$ (4) geographic "Areas of Concern" for which so-called Remedial Action Plans can then be developed; ${ }^{168}$ (5) "Lakewide Management Plans for Critical Pollutants"; ${ }^{169}$ and (6) increased public involvement. ${ }^{170}$

As this brief review illustrates, a conceptual evolution of international freshwater regimes has already begun to take place. In our view, future efforts should continue to emphasize substantive ecosystem orientation, relying on the emerging ecosystem concepts to guide the formation of regimes. The failure of the ILC to incorporate these concepts into its draft articles on international watercourses underscores the difficulties that may arise when regime building approaches the normative stage. The experience of the Helsinki Convention, by contrast, suggests that some of these difficulties can be alleviated by operating in a setting - here a regional contextwhere expectations and positions have begun to converge. As we have argued, where this is not the case, efforts to negotiate binding agreements may be premature. Certainly, the goal of promoting environmental security will not be served in the longer term by agreements that emulate the old sectoral, use-focused and competitive paradigm. Therefore, it may be preferable in individual cases to keep emerging regimes informal or to resort to nonbinding mechanisms to prepare the ground for consolidation according to ecosystem principles. This conclusion, in turn, takes us back to the importance of an appropriate procedural framework to facilitate and reinforce substantive ecosystem orientation.

\section{Promoting Procedural Ecosystem Orientation}

We have already suggested that both international ecosystem law and regime theory point to the need for dynamic and adaptable regimes in which information and viewpoints are freely shared. These features are crucial for contextual regimes, but also for regimes that are crystallizing or have already crystallized into legally binding form. For this reason, we argue that the framework-protocol model, adopted in most modern environmental protection and cooperation regimes, is also best suited to consolidating regimes in the context of shared freshwater resources.

Regrettably, the ILC's draft articles do not sufficiently reflect this approach. While couched in terms of a framework, ${ }^{171}$ the articles do not envisage dynamic evolution within a regime. The structures proposed are rigid and weakly articulated. States are presumed to be the sole actors within the issue-area, and little guidance is offered as to institutional structures that could facilitate the growth of a watercourse regime. Although the ILC's commentary asserts that draft Article 24 is "designed to provide guidance to watercourse States with regard to the powers and functions that could be entrusted to such joint mechanisms or institutions," the provision itself belies these good inten-

\footnotetext{
165 See, e.g., 1987 Protocól, supra note 157, Art. XVI, amending 1978 GLWQA, supra note 154, to add Annex 12(8) (on reporting), \& 1978 GLWQA, Annex 4(5).

${ }^{166} 1987$ Protocol, supra note 157, Supp. to Annex 1, para. 2(c) (i) - (iii). List 1 relates to substances that are toxic and present in the Great Lakes; list 2 deals with substances that have the potential to be toxic and are present in the Great Lakes; and list 3 concerns substances that are toxic but not yet present in the Great Lakes.

${ }^{167}$ See id., Supp. to Annex 1, para. 2(a).

${ }^{168}$ See id., Annex 2, paras. 3, 4.

${ }^{169}$ See id., Annex 2, para. 6.

${ }^{170}$ See id., Supp. to Annex 1, para. 2(a), and Annex 2, para. 2(e).

${ }^{171}$ See ILC 1994, supra note 74, Art. 2 and commentary, at 206.
} 
tions. ${ }^{172}$ Article 24 stands in stark contrast to an earlier version (at the time draft Article 26) proposed by then Special Rapporteur Stephen McCaffrey in his sixth report in $1990 .{ }^{173}$ On the basis of a review of treaty practice, the work of various international organizations, and the efforts of previous ILG Special Rapporteurs Evensen and Schwebel, McCaffrey had drafted a provision that would have offered considerably more "guidance" to states. ${ }^{174}$ However, the Commission apparently considered it more appropriate for Article 24 to leave the determination of details, particularly the functions of a joint institution, to the parties to any future watercourse agreement. ${ }^{175}$

${ }^{172}$ Draft Article 24 provides:

1. Watercourse States shall, at the request of any of them, enter into consultations concerning the management of an international watercourse, which may include the establishment of a joint management mechanism.

2. For the purposes of this article, "management" refers, in particular, to:

(a) planning the sustainable development of an international watercourse and providing for the implementation of any plans adopted;

(b) otherwise promoting rational and optimal utilization, protection and control of the watercourse.

$I d$. at 302. Some commentators have nonetheless evaluated the provision favorably. See, e.g., Sergei V. Vinogradov, Observations on the International Law Commission's Draft Rules on the Law of the Non-Navigational Uses of International Watercourses: 'Management and Domestic Remedies,'3 Colo. J. INT'L ENVTL. L. \& POL'Y 234, $236-37$ (1992) (observing that, "[a]lthough very general in scope and content, . . . this provision reflects the generally recognized need for integrated management of an international watercourse" and that it "reflects a distinct shift from the doctrine of non-harmful use of the State's territory . . . to the concept of the community of interests of watercourse States"). Vinogradov points to extensive discussions in the ILC and the Sixth Committee, which led to the elimination of all controversial aspects of Article 26. Id. at 239. A majority of observers, however, seem critical of the ILC's approach to Article 26. See, e.g., Radosevich, supra note 78, at 262, 266; and Constance D. Hunt, Implementation: Joint Institutional Management and Remedies in Domestic Tribunals (Articles 26-28, 30-32), 3 COLO. J. INT'L ENVTL. L. \& Pol'y 281, 284 (1992). Note that these commentators were referring to draft Article 26 as contained in Report of the International Law Commission on the work of its forty-third session, UN GAOR, 46th Sess., Supp. No. 10, at 170, UN Doc. A/46/10 (1991). Draft Article 24, as adopted in 1994, is identical in wording.

${ }^{173}$ McCaffrey, Sixth Report, supra note 77, at 48.

174 The proposed draft Article 26, id., read:

1. Watercourse States shall enter into consultations, at the request of any of them, concerning the establishment of a joint organization for the management of an international watercourse [system].

2. For the purposes of this article, the term "management" includes, but is not limited to, the following functions:

(a) implementation of the obligations of the watercourse States under the present articles, in particular the obligations under parts II and III of the articles;

(b) facilitation of regular communication, and exchange of data and information;

(c) monitoring international watercourse[s] [systems] on a continuous basis;

(d) planning of sustainable, multi-purpose and integrated development of international watercourse[s] [systems];

(e) proposing and implementing decisions of watercourse States concerning the utilization and protection of international watercourse[s] [systems]; and

$(f)$ proposing and operating warning and control systems relating to pollution, other environmental effects of the utilization of international watercourse[s] [systems], emergency situations, or water-related hazards and dangers.

3. The functions of the joint organization referred to in paragraph 1 may include, in addition to those mentioned in paragraph 2 , inter alia:

(a) fact-finding and submission of reports and recommendations in relation to questions referred to the organization by watercourse States; and

(b) serving as a forum for consultations, negotiations and such other procedures for peaceful settlement as may be established by the watercourse States.

${ }^{175}$ See Vinogradov, supra note 172 , at 241 . Benvenisti, supra note 35 , at 414 , argues that the ILC's reluctance to provide a blueprint for joint management is surprising in view of the optional nature of the draft articles. He concludes, in our view correctly, that the ILC's juxtaposition of a weak joint management provision and a detailed dispute settlement article conveys entirely the wrong signal, promoting adversarial, single-issue approaches rather than long-term cooperation. 
The benefits of flexibility in institutional design are documented by the development of the U.S.-Canada boundary waters regime to date. Since its inception in the 1909 Boundary Waters Treaty, ${ }^{176}$ this regime has been able to reinvent itself and adapt to new concerns. It was partly in response to the IJC's urgent calls for action that the United States and Canada negotiated the 1972 GLWQA. ${ }^{177}$ The IJC, established by the Boundary Waters Treaty, ${ }^{178}$ became the institutional core of the GLWQA and as such has contributed significantly to the evolution of the Great Lakes regime. ${ }^{179}$ It has been assisted in its tasks by the Great Lakes Water Quality Board and the Great Lakes Science Advisory Board, created under the 1972 and 1978 Agreements, respectively. ${ }^{180}$

The success of the IJC and the two advisory boards is largely due to the opportunities they provide for interaction and exchange among scientists, technical experts and policy makers from the two countries. Although the IJC has certain regulatory, arbitral and judicial functions, ${ }^{181}$ its role as meeting place and facilitator has assumed primary importance. Clearly, the example of the IJC is rooted in its unique history, and in the close relations between the two states party to the Agreements, and is not readily transferable to other settings. ${ }^{182}$ What is transferable, however, is the idea that an institution's ability to nurture epistemic communities and depoliticize the discussion of common concerns probably augurs more for its success than an impressive array of regulatory or other powers. ${ }^{183}$ The significance of this dimension has been confirmed both by the work of regime theorists and by the experience of recent international environmental protection regimes. ${ }^{184}$ Similarly transferable is the experience arising from the requirement under the GLWQA that information exchange and consultations occur continuously, and not merely in relation to transboundary harm or equitable utilization. ${ }^{185}$ Partly because of the regime's ecosystem approach, environmental concerns have come to be treated for what they are: common concerns of the parties. The six thematic amendments of the 1987 Protocol further underscore the interaction and mutual reinforcement of procedure and substance.

The GLWQA also illustrates the importance of a structure that permits adaptation and expansion. The GLWQA achieves the necessary dynamism and flexibility in various

${ }^{176}$ Supra note 69.

${ }^{177}$ Bilder, supra note 159 .

${ }^{178}$ See supra note 77.

${ }^{179}$ Pursuant to Article VI of the 1972 GLWQA, supra note 153 , the IJC is responsible, inter alia, for the collection, analysis and dissemination of data, the provision of advice and assistance to the parties, and the investigation of and reporting on water quality issues referred to it by the parties. The IJC may also prepare and publish reports on its own initiative and can exercise all powers conferred upon it by the Boundary Waters Treaty.

${ }^{180}$ See id., Art. VII(1), and 1978 GLWQA, supra note 154, Art. VIII(1)(a).

${ }^{181}$ See supra note 82.

${ }^{182}$ Alan E. Boyle, Remarks at a Workshop on Environmental Security and Freshwater Resources, held at the Faculty of Law, McGill University (Nov. 11-12, 1994) (minutes on file with authors) [hereinafter Workshop].

${ }^{183}$ This view was confirmed by Philip Slyfield (IJC) and Dennis Davis (Environment Canada) in their Remarks at the Workshop, supra note 182. They observed that commissioners and board members take off their "governmental hats" and interact at a professional level, emphasizing personal expertise rather than political interest. They suggested further that, if the IJC had more influence over sovereign interests and were given more regulatory powers, it would "become part of the problem."

${ }^{184}$ See text at notes 46-57 and 108-16 supra.

${ }^{185}$ By contrast, the ILC draft articles, supra note 74, appear to follow the traditional approach. The commentary illustrates the link between substantive and procedural obligations. The commentary on Article 9 (regular exchange of data and information) clarifies that the provision is intended to enable watercourse states to comply with their obligations of equitable utilization and avoidance of significant harm, see id. at 250. The notification and consultation provisions (Arts. 12-19) are specifically tied to planned measures "which may have a significant adverse effect upon other watercourse States," see id., Art. 12, at 260. Similarly, the earlywarning provision is predicated on the presence of an "emergency" causing or threatening serious harm, see $i d$., Art. 28, at 312. For references to treaties containing comparable provisions, see pages indicated in this footnote. 
ways. The objectives outlined in the Agreement itself are fleshed out and implemented through a series of annexes dealing with specific aspects of ecosystem-oriented basin management. ${ }^{186}$ These issue-specific annexes not only allow for the necessary detail, ${ }^{187}$ but also provide for various modes of amendment and expansion independently of the GLWQA itself. ${ }^{188}$ This possibility for adjustment is above and beyond what the GLWQA already provides for: the review and possible modification of its objectives and programs, as well as the amendment of the Agreement and its annexes, in response to the findings in the IJC's biennial reports. ${ }^{189}$

Although this terminology is not used in it, the GLWQA has much in common with the framework-protocol model mentioned above. The GLWQA itself is cast in general terms, defining the regime's central policy goals, providing for an institutional structure and allowing for "subagreements" - in this case annexes - that can address individual aspects of the broader concerns. The success of the GLWQA, arguably the most evolved regime of its kind, supports our assertion that the framework-protocol model is particularly suited to promoting the consolidation and continued growth of ecosystem-oriented freshwater regimes. In our view, this conclusion is relevant to freshwater regimes both among industrialized countries and among developing countries. Achieving ecosystem orientation in either setting requires an approach to regime building that is sensitive to a diversity of interests and the need to nurture areas of shared or common interest. Although the freshwater agreement combining most of the features we argue for - the GLWQA - developed between two industrialized countries with a long history of friendly relations, we believe that its approach has broader relevance. As noted, evidence of substantive ecosystem orientation can be found in many recent freshwater regimes negotiated among developing countries, and the framework-protocol model has proven itself in various settings characterized by significant developing country participation.

Experience with the framework-protocol model in international environmental law outside the freshwater context confirms that the framework component is conducive to broad participation, elaboration and agreement on general governing principles, identification of basic common interests, and settling of institutional and procedural questions. ${ }^{190}$ Given the relatively low level of initial commitment, the framework makes it easier to define common interests broadly, according to ecosystem-oriented concepts such as the drainage basin, sustainable development, intergenerational equity and precaution. ${ }^{191}$ Furthermore, because the commitments required by the framework are not

${ }^{186}$ The annexes to the GLWQA, as amended by the 1987 Protocol, supra note 157, are (1) Specific Objectives; (2) Remedial Action Plans and Lakewide Management Plans; (3) Control of Phosphorous; (4) Discharges of Oil and Hazardous Polluting Substances from Vessels; (5) Discharges of Vessel Wastes; (6) Review of Pollution from Shipping Sources; (7) Dredging; (8) Discharges from Onshore and Offshore Facilities; (9) Joint Contingency Plan; (10) Hazardous Polluting Substances; (11) Surveillance and Monitoring; (12) Persistent Toxic Substances; (13) Pollution from Non-Point Sources; (14) Contaminated Sediment; (15) Airborne Toxic Substances; (16) Pollution from Contaminated Groundwater; and (17) Research and Development.

${ }^{187}$ See, e.g., id., Annex 1 (defining allowable concentrations of pollutants to maximum microgram per liter unit).

${ }^{188}$ For example, the 1978 GLWQA, supra note 154, Annex 1, allows the amendment or addition of objectives by "mutual consent of the Parties." Annex 10 adopts a similar approach with respect to "hazardous polluting substances" and goes so far as allowing each party, upon notification of the other, to make unilateral additions to a list of "potential hazardous polluting substances" (para. 4(a)).

${ }^{189}$ See id., Arts. X, XIII.

${ }^{190}$ Examples include the (ECE) Convention on Long-Range Transboundary Air Pollution, Nov. 13, 1979, TIAS No. 10,541, reprinted in 18 ILM 1442 (1979); the Vienna Convention, supra note 109; the Framework Convention on Climate Change, May 9, 1992, UN Doc. A/AC.237/18(Part II)/Add.1 \& Corr.1, reprinted in 31 ILM 849 (1992). See Jutta Brunnée, Towards Effective International Environmental Law: Trends and Developments, in Law and Process in EnVironmental Management 217, 223-26 (S. A. Kennett ed., 1993).

${ }^{191}$ See in this regard the Danube Action Plan, supra note 153, the Executive Summary of which states: "Despite the diversity of problems, interests and priorities across the Danube River basin, the countries share certain important values and have agreed on principles which underlie the goals and actions of the Plan" (emphasis added). The plan then outlines a series of "common goals," "common strategic directions," "common targets" and "common actions." The Danube Action Plan is intended to "support and implement" the 
specific, it can accommodate riparians and nonriparians alike. ${ }^{192}$ In addressing basic procedural and institutional questions, the framework also contributes to the growth of decision-making processes that will be perceived as legitimate by those involved in the regime. It effects a "gelling" of cooperative practice but does not "freeze" it. Rather, it anchors a dynamic process that can spawn protocols as individual questions arise and common ground emerges.

Protocols make it possible to involve different groupings of parties in issues of concern to them. ${ }^{193}$ In particular, they allow the involvement of nonriparians in some issues, but not in others. Because protocols are focused on relatively narrow issues, they also permit the regime to combine the benefits of ecosystem orientation, at the framework level, with those of a sectoral approach. Thus, the protocols facilitate agreement on specific and binding standards that, in turn, help to flesh out the ecosystem principles contained in the framework. ${ }^{194}$ These broader principles may then become more widely accepted and can crystallize into binding custom. One of the strengths of the framework-protocol model is that it accommodates and promotes the important interplay between contextual and normative elements of regime formation and development. While serving to consolidate a regime into legally binding form, the model retains contextual elements, ${ }^{195}$ allowing for the dynamism and fluidity so valued by regime theory and by what we have called international ecosystem law. ${ }^{196}$

Given the importance of dynamic development, we suggest further that, in the early stages of regime formation, explicit attempts to define noncompliance for the purposes of penalties be avoided. ${ }^{197} \mathrm{~A}$ soft approach to obligations is likely to facilitate the confidence building necessary for the creation of a regime, as well as encourage broader participation by states, an essential element if an ecosystem focus of a freshwater regime is to be achieved. Implementation should be viewed initially as a question of facilitation and encouragement, rather than as an issue to be addressed through the creation of institutions with forms of legal jurisdiction to enforce obligations. As contextual regimes evolve into legal frameworks, formal mechanisms to promote compliance may become appropriate. Working groups to assess the information on which state action is based and to suggest lines of suitable conduct may prove helpful. Technical commissions may be created. We have already suggested that such institutions may themselves serve as epistemic communities to promote the further definition of obligations and the imple-

Convention on Cooperation for the Protection and Sustainable Use of the Danube Basin, supra note 153, even before the Convention enters into force ( 90 days after ratification by the ninth country). In addition to these initiatives, the Danube countries are negotiating a draft Danube Basin Ecological Convention.

${ }^{192}$ See, e.g., the distinction between "parties" and "riparian parties" in the Helsinki Convention, supra note 143, Art. 1(3) and (4). All "parties" are subject to certain basic environmental protection and ecosystem management obligations (Arts. 2-8), whereas "riparian parties" are subject to additional provisions on cooperation and joint management of the water resource (Arts. 9-16).

${ }^{193}$ See Setear, supra note 11.

${ }^{194}$ See Brunnée, supra note 15.

${ }^{195}$ Clearly, protocols are intended to be sources of formal legal obligations. By contrast, the framework agreement, while technically binding, is so broadly phrased as to partake of more of the values of a contextual regime.

${ }^{196}$ A similar argument, albeit not in the context of international ecosystem law, is advanced by Setear, supra note 11. He calls for an "iterative" approach to treaty making, a proposal that intersects with our idea of a continuum in regime formation. Relying on findings derived from game theory, Setear argues, id. at 185-89, that cooperation is more likely to emerge among states when they are involved in an indeterminate series of interactions, as opposed to one single interaction. He suggests, $i d$. at 186, that "[t] he placement of a sufficiently high value on future interactions allows a player rationally to trade off short-term gains." Therefore, Setear, too, concludes that the framework-protocol model, because of its multiple "iterations" from the initial agreement to subsequent protocols, is particularly conducive to a cooperative dynamic. Id. at 217-24. See also Benvenisti, supra note 35, at 392, 399-400.

${ }^{197}$ See further CHAYES \& CHAYES, supra note 16, at 108. 
mentation of norms that evolve over time. ${ }^{198}$ As the political legitimacy of the contextual regime grows, the legal dimension may be strengthened and even more formal institutions may be created: conciliation or mediation attempts may be undertaken. Ultimately, as the regime becomes more structured and legal legitimation takes place, binding rules and mechanisms of dispute settlement may prove to be acceptable and effective. But this eventuality will tend to occur well along in the process of regime building. ${ }^{199}$

The development of implementation, dispute avoidance and dispute resolution that we have described, like the process of regime formation itself, is not strictly linear. For particular questions within a given issue-area, the approach to implementation and the regulation of disputes may possess distinctive elements. If cooperation on particular technical questions has advanced quickly, for example within the ambit of individual protocols to a framework agreement, processes of dispute avoidance relating to those questions may evolve just as quickly. Scientific commissions may be accorded the power to define and regulate disputes relating to the interpretation of data. But this does not imply that on other questions the members of the regime will be ready for the same forms of compliance monitoring. However, the success of narrowly focused mechanisms to promote compliance may help to build confidence within the regime, enhancing political and legal legitimacy and encouraging the expansion of the dispute-identifying and -resolving processes into new areas. This point underscores how important incremental progress may be in rooting a regime and allowing for further growth in the scope of both substantive and procedural obligations.

\section{CONCLUSION}

Our analysis of the interplay between regime theory and international ecosystem law prompts four concluding observations. First, regime theory can provide international lawyers with important insights into the processes of normative evolution along a continuum from the mere exchange of views to legally binding rules. Legal norms, both customary and conventional, are likely to arise only from contextual regimes in which political and juridical legitimacy has been established. For that reason, all stages in regime evolution possess independent value. Nonetheless, attention must be paid throughout to the elaboration of general principles that will nurture the further development of the regime and continue to build legitimacy by fostering processes that provide for appropriate participation in regimes and communication among their members.

Second, ecosystem-oriented principles such as sustainable development, intergenerational equity, precaution, common concern, and the drainage basin focus are likely to encourage a sense of legitimacy because they implement the fundamental legal values of equality, transparency, justice and fairness. In any event, without these ecosystemoriented principles, no freshwater regime is likely to promote environmental security in the longer term.

Third, aside from the conceptual interest of insights from regime theory, an appreciation of the continuous normative evolution within regimes is fundamental to the development of international ecosystem law. It also demands a commitment to future-oriented

\footnotetext{
${ }^{198}$ On the importance of providing avenues for the evolution of norms in promoting compliance, see also $i d$. at 110, characterizing the compliance process as "a kind of discourse," and $i d$. at 123, suggesting that the "discursive elaboration and application of treaty norms is the heart of the compliance process."

${ }^{199}$ The ILC's draft articles, ILC 1994, supra note 74, do not pay sufficient attention to these considerations. They follow the tradition of formal dispute resolution processes. The ILC members were divided on the value of including dispute settlement clauses in the draft articles. See Report of the International Law Commission on the work of its forty-fifth session, UN GAOR, 48th Sess., Supp. No. 10, at 220-22, UN Doc. A/48/10 (1993). Draft Article 33 now provides a stepped procedure, culminating in arbitration or adjudication, to be employed in the absence of an applicable agreement between watercourse states.
} 
principles and dynamic processes. For such law to be effective, the ecosystem orientation must be both substantive and procedural. The principles mentioned above must be the conceptual cornerstones of regimes that, at the same time, provide for processes to promote the identification of common interests and the involvement of all relevant players. Sufficient flexibility is needed to adapt regimes to changing circumstances. The framework-protocol model already adopted in a few environmental contexts is best suited to achieving this procedural ecosystem orientation and to ensuring the necessary interplay between substantive and procedural elements in the context of shared freshwater resources. This model also advances the strengths of a contextual regime into the process of legal consolidation.

Fourth, concerns over legitimacy and efficacy of freshwater regimes prompt a reassessment of currently prevalent attitudes toward the implementation of norms. Premature attempts to generate binding legal norms are unlikely to solicit adherence, leading to the perception of the regime as ineffective. The typical response, to demand more stringent enforcement, will not result in greater effectiveness when there is no underlying belief in the legitimacy of the regime. For that reason, the creation of binding dispute resolution mechanisms in the early stages of regime formation will almost inevitably produce paper tigers. The mechanisms will rarely be employed. A greater contribution to effective normativity can be made in the contextual stages of regime development through informal and nonbinding processes directed at the implementation and progressive development of norms. Once a regime has hardened, and acquired political and legal legitimacy, binding dispute resolution may become appropriate. 